\title{
The Effects of Exogenous Polyamines and the Silencing of RLCK VI_A Kinases on the Polar Growth of Nicotiana tabacum (Tobacco) Pollen Tubes
}

PhD thesis

Shyam Jee

Supervisor: Prof. Dr. Attila Fehér

Co-supervisor: Dr. Katalin Gémes

Institute of Plant Biology

Biological Research Centre

University of Szeged

2019 


\section{TABLE OF CONTENTS}

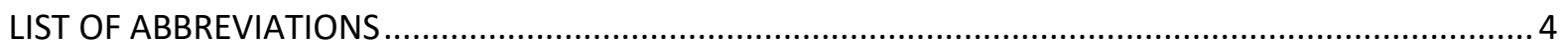

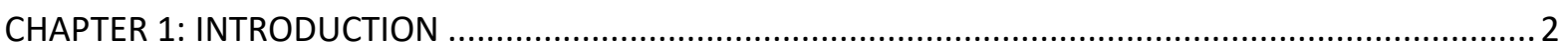

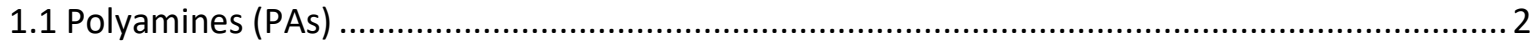

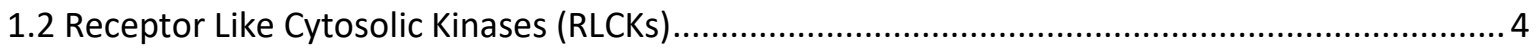

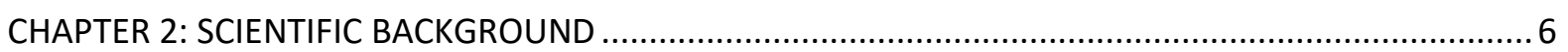

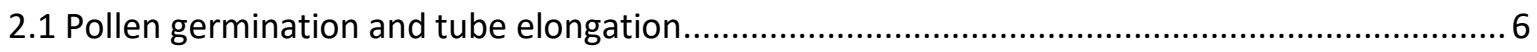

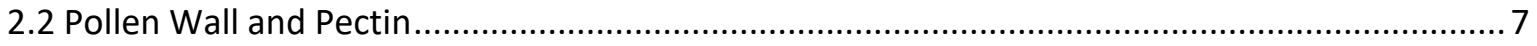

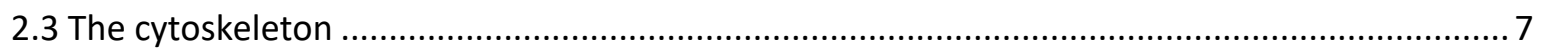

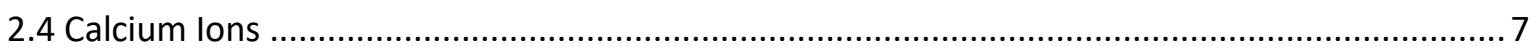

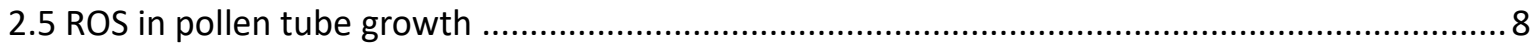

2.6 Exocytosis/Endocytosis in pollen tubes........................................................................... 10

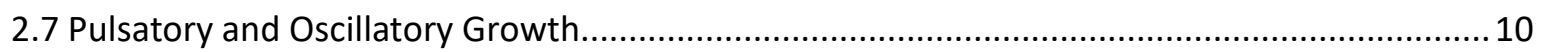

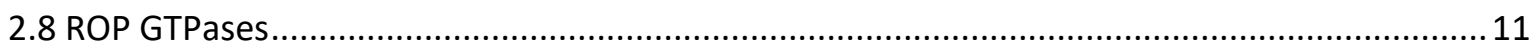

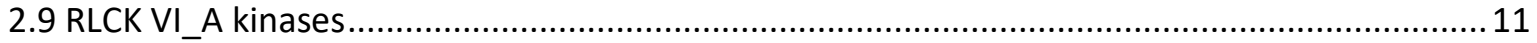

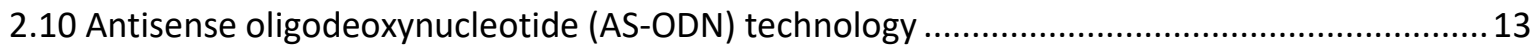

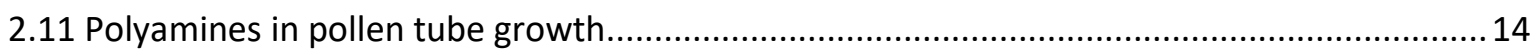

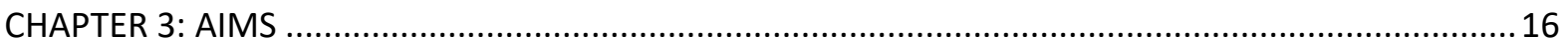

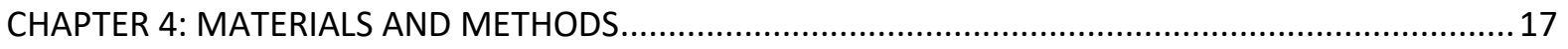

4.1 Plant material, pollen germination and growth condition ..................................................17

4.2 In situ detection of nitric oxide and reactive oxygen species ...............................................17

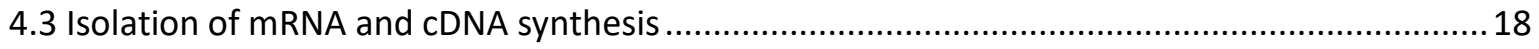

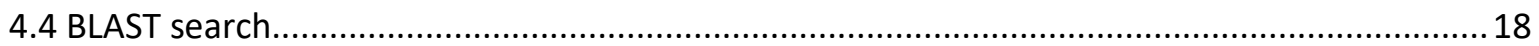

4.5 Cloning and sequencing of PCR amplified Nicotiana tabacum kinase sequences .....................18

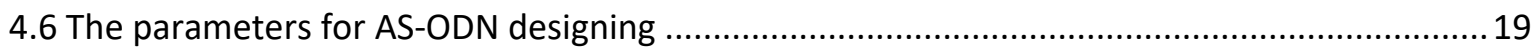

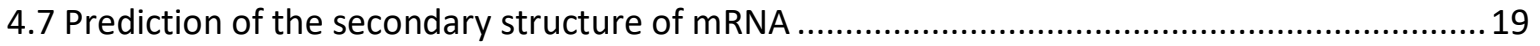

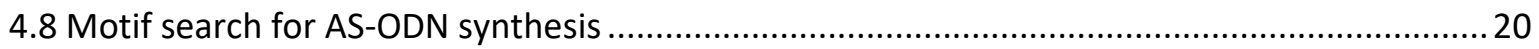

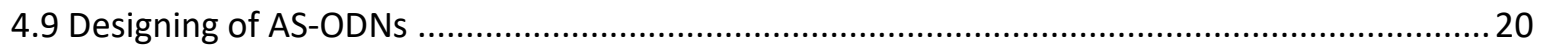

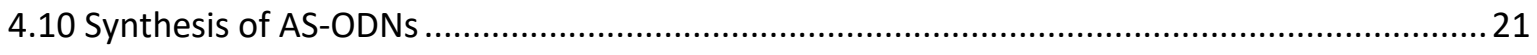

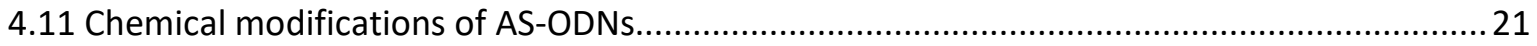




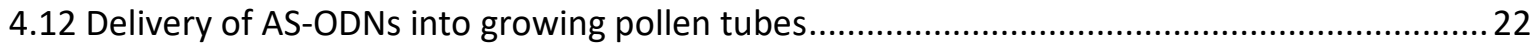

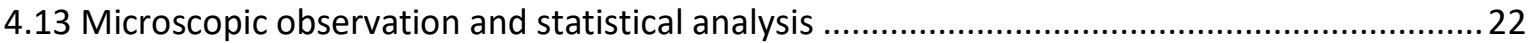

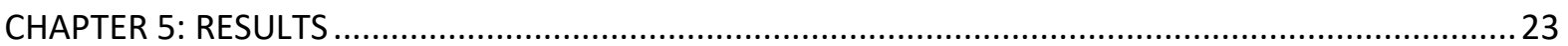

5.1 Effect of exogenous polyamines on the growth of pollen tubes ..........................................2 23

5.1.1 The various polyamines affect tobacco pollen grain germination dependent mainly on the

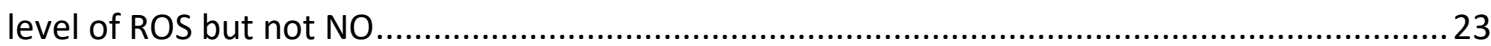

5.1.2 Exogenous polyamines affect tobacco pollen tube growth differentially altering the

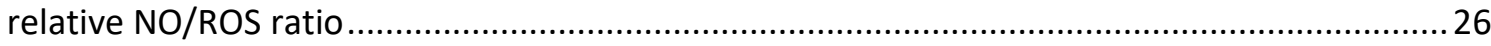

5.2. The role of RLCK VI_A family kinases in pollen tube growth and polarity ...............................30

5.2.1 Identification of Nicotiana tabacum RLCK VI_A kinase cDNA sequences ............................30

5.2.2 Gene expression analysis of Nt RLCK VI_A in pollen and leaves of Nicotiana tabacum ......32

5.2.3 Verification of Nicotiana tabacum RLCK VI_A sequences before the AS-ODN design........33

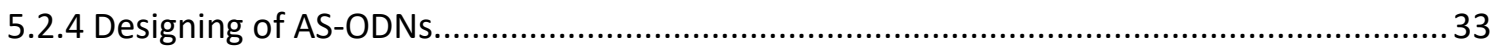

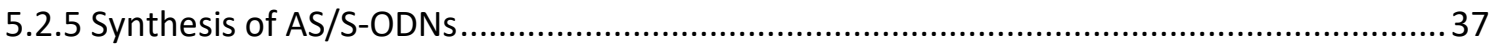

5.2.6 Effect of AS-ODN treatment on Nicotiana tabacum pollen .............................................. 38

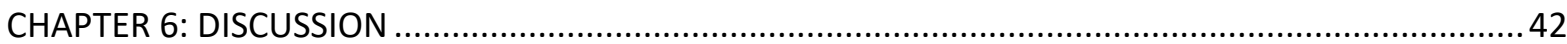

6.1 The effect of exogenously applied polyamines (PAs) on pollen germination and the apical

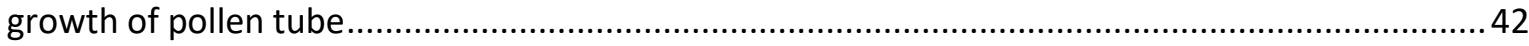

6.2 The functional analysis of the RLCK Class VI_A family in tobacco pollen tubes........................44

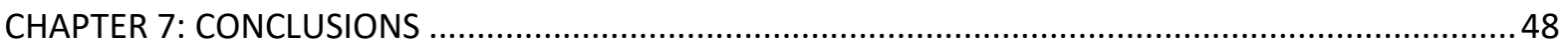

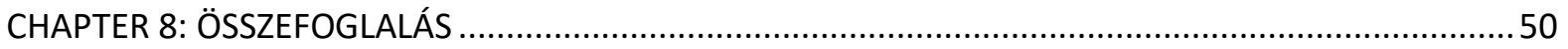

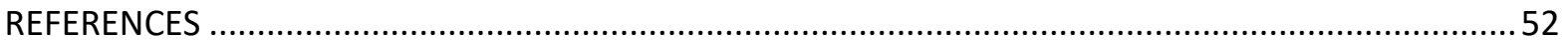

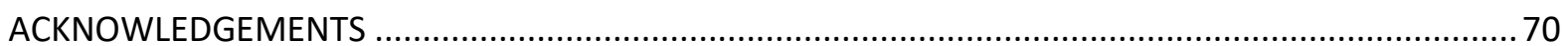




\section{LIST OF ABBREVIATIONS}

At - Arabidopsis thaliana

ADC - Arginine decarboxylase

AF - Actin filaments

AOs - Amine oxidases

AS - Antisense

BIK1 - Botrytis Induced kinase1

cDNA - Complementary DNA

cPTIO - 2-(4-carboxyphenyl)-4, 4, 5, 5tetramethylimidazoline-1-oxyl-3-oxide

SNAP - S-Nitroso-N-acetyl-D,L-penicillamine

DAOs - Diamine oxidases

DAF-FM DA - 4-amino-5-methylamino-2', 7'difluorofluorescein diacetate

DCF - Dichlorofluorescein

DMTU - N, N'-Dimethylthiourea

1, 3-DAP - 1, 3-diaminopropane

ETS - Electron transport system

GTP - Guanosine triphosphate

GDP - Guanosine diphosphate

His - Histidine

$\mathrm{H}_{2} \mathrm{O}_{2}$ - Hydrogen peroxide

H2DC-FDA - 2, 7-dichlorodihydro-fluorescein diacetate

MF - Microfilaments

mRNA - Messenger RNA

MES/KCl - 2-N-morpholine-ethanesulphonic acid/potassium chloride

MGBG - Methylglyoxal-bis (guanyl-hydrazone)

MT - Microtubules

MAPK - Mitogen-activated protein kinase

MLPK - M-locus protein kinase

MT - Microtubules

NADH - Nicotinamide adenine dinucleotide

NO - Nitric oxide
NOX - NADPH oxidase

Nt - Nicotiana tabacum

ODN - Oligodeoxynucleotide

ODC - Ornithine decarboxylase

PA - Polyamine

PME - Pectin methylesterase

PAOs - Polyamine oxidases

PS - Phosphorothioate

Put - Putrescine; di-amine putrescine

P5CR - Pyrroline-5-carboxylate reductase

P5CS - $\Delta^{1}$-pyrroline-5-carboxylate synthetase

PCD - Programmed cell death

RK - Receptor kinase

RTKs - Receptor tyrosine kinases

ROS - Reactive oxygen species

RNS - Reactive nitrogen species

RT PCR - Reverse transcription polymerase chain reaction

RLK - Receptor like kinase

RLCK - Receptor like cytoplasmic kinase

ROP - Rho of plant

Spd - Spermidine; tri-amine spermidine

Spm - Spermine; tetra-amine spermine

SPDS - Spermidine synthase

SPMS - Spermine synthase

SNP - Sodium nitroprusside

SAMDC - $S$-adenosylmethionine decarboxylase

S - Sense

siRNA - Short interfering RNA

SNP - Sodium nitroprusside

SPDS - Spermidine synthase

SPMS - Spermine synthase

siRNA - Short interfering RNA

tSpm - Thermospermine 


\section{CHAPTER 1: INTRODUCTION}

Several genetic and/or environmental factors such as air, temperature, humidity can have harmful effect on fruit- and seed-set in seed plants. To minimize the harmful effect of these factors, it is important to get more information on the underlying genetics and physiology of pollen biology, including pollen viability and the regulation of pollen germination and tube growth, which is required to increase the safety of crop productivity (Abdelgadir, Johnson, and Staden 2012). In this thesis, two different experimental approaches were described to better understand the role of polyamines and plant-specific kinases (RLCK VI_A), respectively, on pollen tube germination and growth in Nicotiana tabacum.

\subsection{Polyamines (PAs)}

Polyamines (PAs) are small polycationic organic molecules, containing amino groups, present in cytosol and organelles. The PAs are naturally occurring in the cell as free and bound form and their polycationic nature is due to the spatial distribution of total charge. PAs play an important role in cell growth including pollen tube development in several species (Aloisi, et al. 2016; Pegg and Casero 2011).

Polyamines are synthesized from the amino acids, namely from arginine, ornithine and methionine. Arginine is converted to ornithine by the mitochondrial enzyme arginase. Ornithine decarboxylase decarboxylate ornithine to produce putrescine (Put). Decarboxylated S-adenosyl-L-methionine is then used to add an aminopropyl group to putrescine by spermidine synthase to produce spermidine ( $\mathrm{Spd})$, or to spermidine to produce spermine (Spm) by spermine synthase.

PAs are catabolized by two classes of amine oxidases (AOs) such as polyamine oxidases (PAOs) and diamine oxidases (DAOs) (Moschou and Roubelakis-angelakis 2013). The copper-containing diamine oxidases (DAOs) oxidize putrescine (Put) yielding hydrogen peroxide $\left(\mathrm{H}_{2} \mathrm{O}_{2}\right)$ and amino aldehydes. The apoplastic flavoprotein PAO terminally oxidizes spermidine (Spd) and spermine (Spm), but not putrescine (Put) yielding $\Delta^{1}$-pyrroline, 1,3diaminopropane (1,3-DAP) and $\mathrm{H}_{2} \mathrm{O}_{2}$ (Moschou and Roubelakis-angelakis 2013). $\mathrm{H}_{2} \mathrm{O}_{2}$ 
regulates $\mathrm{Ca}^{2+}$ influx, thereby a high $\mathrm{Spd}$ concentration enhances $\mathrm{Ca}^{2+}$ influx beyond the optimal, and thus has a deleterious effect (Wu et al. 2010). On the contrary, different studies have demonstrated the efficient action of PAs in ROS scavenging (Aloisi,et al. 2015). PAs are able to reduce oxidative damage that occurs due to drought and water stress. They can enhance stress tolerance e.g. by elevating de novo synthesis of antioxidant enzymes and reducing lipid peroxidation (He et al. 2008; Romero 2015).

Exogenous application of PAs into pollen culture strongly affects pollen maturation, germination, and tube elongation depending on the dose and structure of PAs (Aloisi, et al. 2016; Aloisi, et al. 2015; Singh and Tandon 2012). Despite the number of studies about the role of PAs in pollen germination and growth, it is still largely unclear by which mechanisms PAs take part in the regulation of these processes. ROS as well as NO serve as signalling molecules in plants and affect the control and regulation of many physiological and developmental processes and cell functions (Gémes et al. 2011). NO plays an important role in the regulation of tip growth, especially pollen tube growth (Neill et al. 2008; Prado, Porterfield, and Feijó 2004). Despite the accumulating experimental data about the role of polyamines, ROS and NO, respectively, in pollen germination and growth we have limited information about the interconnection of these compounds in these processes.

The study presented in the first half of this thesis focuses on investigations related to the effect of exogenous polyamines on tobacco pollen germination and growth through their influence on ROS and NO production. 


\subsection{Receptor Like Cytosolic Kinases (RLCKs)}

Plants have a unique family of small GTPases, which termed as Rho-of-plants (ROPs). ROP GTPases are members of the RAS superfamily of small GTP-binding proteins, which function as two-state molecular switches depending on their confirmation such as GDP-bound (inactive form) or GTP-bound (active form) (Jurca 2011; Lundquist 2006; Wennerberg, Rossman, and Der 2005). The ROP GTPases have many effector and regulator partners including potential ROP effector kinases, which belong to the large family of plant receptor-like kinases (RLK) (Dorjgotov et al. 2009; Jurca et al 2008).

RLK family members represent around $2.5 \%$ of the protein-coding genes in Arabidopsis thaliana. RLK family divided into three large groups of proteins based on domain organizations considering an extracellular domain, an intracellular kinase domain, and transmembrane domain. These are receptor kinases (RLKs), receptor-like proteins (RLPs; lacking protein kinase domains) and receptor-like cytosolic kinases (RLCKs; lacking extracellular receptor domains) (Shiu and Bleecker 2003). Phosphorylation plays a key role in regulating the activities of receptor complexes (Dua et al. 2016; Kadota, Shirasu, and Zipfel 2015; Kolbert et al. 2015; Liang and Zhou 2018). Among others, RLKs phosphorylate the ROP guanine nucleotide exchange factors (RopGEFs) and thus activate ROP-dependent signalling pathways (Fehér and Lajkó 2015).

The potential ROP effector kinases belong to the RLCKs, namely to the class RLCK VI, group A (RLCK VI_A). The At RLCK VI kinase family has 14 members belonging to two groups in Arabidopsis (Jurca et al. 2008), the first group is RLCK VI_A (ROP- interacting), having N-terminal serine-rich domain and the second group RLCK VI_B (ROP - non-interacting) having N-terminal UspA domain (Kerk et al. 2003). The member of these groups were designated accordingly such as RLCK VI_A1-A7 and B1-B7 (Jurca et al. 2008).

Several common functions of RLKs and ROPs have been reported including their involvement in pollen-pistil interaction (Kachroo, Nasrallah, and Nasrallah 2002; Fehér and Lajkó 2015; Liang and Zhou 2018). On the other side, very limited information is available about the 
function of receptor-like cytoplasmic kinases including those belonging to the ROP-regulated RLCK VI_A group and exhibiting strong expression in the pollen.

The antisense oligodeoxynucleotide (AS-ODN) technology is widely used as a genomic tool for the identification of gene function, since it has been discovered by Zamecnik and Stephenson in 1978 in Rous sarcoma virus for inhibition of replication and cell transformation. In plants, the first time AS-ODN was used by Tsutsumi, Kanayama, and Tano in 1992 for the inhibition of barley alpha-amylase gene. In pollen, the first time AS-ODN was used by Estruch et al. 1994 for the inhibition of calcium-dependent calmodulin-independent protein kinase in maize (Zea mays). Later on Moutinho et al. 2001 used AS-ODN for perturbation of protein function in pollen tube of Agapanthus umbellatus, Dinç et al. 2011 used for inhibition of nucleus and chloroplast encoded proteins of chloroplasts in the higher plant, and Mizuta and Higashiyama 2014 for inhibition of ANX1 and ANX2 in Arabidopsis pollen tubes.

We decided to use AS-ODN technology for the functional analysis of RLCK VI_A kinase in Nicotiana tabacum pollen. 


\section{CHAPTER 2: SCIENTIFIC BACKGROUND}

\subsection{Pollen germination and tube elongation}

The pollen grain is released as a fine/coarse powdery substance from the anther in a dehydrated state. In this dehydrated state, pollens are transported over long distances to reach the female apparatus (Lin and Dickinson 1984; Moscatelli and Cresti 1992) called stigma, either by direct contact or mediated by various agents like insects, birds, animals, wind, etc.

The pollen tube is commonly used as a model system to study polar cell growth, which represents a common process in all eukaryotic kingdoms (Breygina et al. 2016; Rounds and Bezanilla 2013). When a pollen grain lands on a stigma it needs to undergo adhesion, hydration (Dresselhaus and Franklin-tong 2013; Kessler and Grossniklaus 2011), pollen germination and pollen tube formation. Pollen tube formation occurs when the pollen grain interacts with a receptive stigma (Chebli and Geitmann 2014). Many genes are involved in this process (Caser 2018; Maruyama et al. 2014).

Several internal factors regulate pollen tube growth such as uptake of calcium ion, turgor pressure, the plasticity of the apical cell wall, and the transport and fusion of Golgi vesicles (Moscatelli and Cresti 1992; Pierson et al. 1995). The growth of the pollen tube in angiosperms depends on the actin cytoskeleton and the actin-binding proteins get regulated by lipid metabolites and ionic conditions (Ren and Xiang 2007), whereas the pollen tube growth of gymnosperm depend on actin and microtubule interactions (Anderhag, Hepler, and Lazzaro 2000; Cheung et al. 2008).

The synergid cell produce chemical gradients (Cheung, Wang, and Wu 1995; Dresselhaus and Franklin-tong 2013; Selinski and Scheibe 2014). The chemical gradients act as signal molecules to attract the pollen tubes. The pollen tube grows through the style and reaches the embryo sac (Ãy, Kuroiwa, and Kuroiwa 2003; J. Derksen et al. 1995). The pollen tube rupture is mediated by three receptor kinases that are FERONIA (FER) in synergid cells and ANXURE 1 and 2 (ANX1 and ANX2) in pollen tube through programmed cell death (PCD) of the receptive synergid cell due to exaggerated $\mathrm{Ca}^{2+}$ responses. The ruptured pollen tube releases two sperm cells; one of them fertilizes the egg cell to produce an embryo, while the other fuses 
with the central cell to produce endosperm (Chai et al. 2015; Higashiyama and Takeuchi 2015; Peng and Sun 2017).

\subsection{Pollen Wall and Pectin}

Pectin, the most complex class of wall polysaccharides, is the major component of the cell wall at the pollen tube tip (Chen, Linskens, and Cresti 1994; Fry 1986; Knox et al. 1990) It has a key role in determining cell wall mechanics. The removal of pectin by pectinase treatment leads to depolarized growth of pollen tubes (Fayant et al. 2010; Yan 2010). During tip growth, the newly synthesized soft pectin esters get exocytosed into the pollen tube apex cell wall with the help of pectin methylesterase (PME). The soft pectin esters get converted into the rigid deesterized pectin. Reduced activity of PME leads to the bursting of pollen tube but the overexpression of PME suppresses pollen tube growth; this indicates the important role of pectin ester level on the strength of the cell wall (Bosch 2005; Yan 2010).

\subsection{The cytoskeleton}

The plant cell cytoskeleton consists mainly of microtubules (MT) and actin microfilaments (MF) (Derksen et al. 1995). Actin MFs accumulate in the apical region of the growing pollen tube where it is involved in the transport of secretory vesicles which is essential for cell elongation (Taylor and Hepler 1997; Yen, Liu, and Cai 1995). However, to allow vesicle fusion with the apical plasma membrane, the actin filaments must be depolymerized resulting in an actin free clear zone at the very tip. There are three major arrays of MTs present in the pollen tube but only the cortical MTs in the vegetative cell cytoplasm participate in pollen tube growth (Ylstrs et al. 1994). The application of anti-MT agents in growing pollen tubes indicates that microtubules (MTs) are responsible for creating/maintaining cytoplasmic zonation (Astrom, Sorri, and Raudaskoski 1995; Taylor and Hepler 1997)

\subsection{Calcium Ions}

The role of $\mathrm{Ca}_{2}{ }^{+}$ion in tip-growth was identified by (Picton and Steer 1982). $\mathrm{Ca}_{2}{ }^{+}$along with other inorganic ions such as potassium, protons, and chloride also participate in pollen germination (Breygina et al. 2012; Hepler et al. 2006; Holdaway-Clarke and Hepler 2003), 


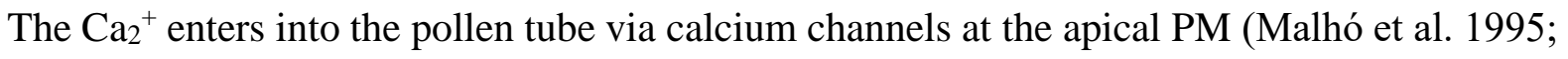
Yan 2010). $\mathrm{A} \mathrm{Ca}^{2+}$ gradient at the tip is essential for pollen tube elongation (Hepler, Vidali, and Cheung 2001), and reorientation (Guan et al. 2013; Steinhorst and Kudla 2012). Removal of tip-focused calcium gradient leads to growth arrest (Holdaway-Clarke, Feijó, Hackett, Kunkel, et al. 1997; Pierson et al. 1996). $\mathrm{Ca}_{2}{ }^{+}$ions regulate the cytoskeleton, secretion of cell wall components (Brewbaker and Kwack 1963; Hepler et al. 2006), and vesicle transport (Hepler et al. 2012). The application of either $\mathrm{Ca}^{2+}$ channel blockers or $\mathrm{Ca}^{2+}$ ionophores inhibit the pollen tube growth, indicating a link between cytosolic $\mathrm{Ca}^{2+}$ concentration and pollen tube elongation (Guan et al. 2013; Picton and Steer 1983).

In addition to $\mathrm{Ca}^{2+}$, pollen tube growth is also regulated by $\mathrm{pH}$ (Fricker, White, and Obermeyer 1997; Hepler and Mckenna 2006). $\mathrm{Ca}^{2+}$ causes stiffness of the unesterified pectin, whereas, a high concentration of $\mathrm{H}^{+}$showed loosening effect (Steinhorst and Kudla 2012).

\subsection{ROS in pollen tube growth}

ROS has dual functions depending on the available concentrations in the cell. ROS at low concentrations act as secondary messengers; regulate numerous physiological and developmental processes in plants, such as cell expansion, polar growth, flower development, regulation of the stomatal aperture, stress responses (Alvarez et al. 1998; Coelho et al. 2002; Gémes et al. 2016, 2017; Moschou and Delis 2008), pollen tube development (Sírováa et al. 2011), as well as pathogen defence (Miller et al. 2010; Mittler 2002; Sagor et al. 2016). However, above the threshold levels, ROS act as a toxic molecule via causing damage to the biomolecules such as proteins and nucleic acids through lipid peroxidation and oxidative modification (Turpaev 2002). The various sources of ROS are given in the table 1.

$\mathrm{Ca}^{2+}$ activates production of ROS by $\mathrm{RbohH}$ and $\mathrm{RbohJ}$ plasma membrane NADPH-oxidases in Arabidopsis. ROS is essential for proper polar growth of pollen tube tip (H. Kaya et al. 2014). ROS get accumulated in the growing tip of pollen tubes. Use of ROS scavengers caused reduction in ROS levels and inhibited pollen tube growth (Kaya et al. 2014; Potocký et al. 2007). In addition to ROS, NO also serves as signalling molecule in the growth and reorientation of pollen tubes (Prado et al. 2004; Pradoa et al. 2008). It was also shown to inhibit 
pollen germination and pollen tube growth in response to UV-B light in Paulownia tomentosa (He et al. 2007).

Table 1: The sources of Reactive Oxygen Species (ROS)

\begin{tabular}{|c|c|c|c|}
\hline ROS & Sources of ROS & Localization & References \\
\hline $\begin{array}{c}{ }^{1} \mathrm{O}_{2} \\
\text { (Singlet } \\
\text { Oxygen) }\end{array}$ & Excited chlorophyll & Chloroplast & $\begin{array}{l}\text { (Liszkay, Fufezan, and Trebst } \\
\text { 2008; Triantaphylidès and } \\
\text { Havaux 2009) }\end{array}$ \\
\hline \multirow{5}{*}{$\begin{array}{l}\quad \mathrm{O}_{2}^{-} \\
\text {(Superoxide } \\
\text { anions) }\end{array}$} & $\begin{array}{l}\text { Photosynthesis ETS } \\
\text { and PSI or II }\end{array}$ & Chloroplast & (Asada 1999) \\
\hline & Respiration ETS & Mitochondria & $\begin{array}{l}\text { (J. Dat, S. Vandenabeele, E. } \\
\text { Vranova', M. Van Montagu } \\
\text { 2000) }\end{array}$ \\
\hline & NADPH oxidase & $\begin{array}{l}\text { Plasma } \\
\text { membrane }\end{array}$ & $\begin{array}{l}\text { (Grant and Loake 2000; } \\
\text { Hammond-Kosack and Jones } \\
\text { 1996) }\end{array}$ \\
\hline & Xanthine oxidase & Peroxisome & $\begin{array}{l}\text { (Corpas, Barroso, and Del Río } \\
\text { 2001) }\end{array}$ \\
\hline & $\begin{array}{l}\text { Peroxidases, } \mathrm{Mn}^{2+} \\
\text { and } \mathrm{NADH}\end{array}$ & Cell wall & $\begin{array}{l}\text { (Grant and Loake 2000; } \\
\text { Hammond-Kosack and Jones } \\
\text { 1996) }\end{array}$ \\
\hline $\begin{array}{c}\mathrm{OH}^{-} \\
\text {(Hydroxyl } \\
\text { radical) }\end{array}$ & $\begin{array}{l}\text { Peroxidase } \\
\text { compound III } \\
\left(\mathrm{Fe}_{3} \mathrm{CO}^{2-}\right)\end{array}$ & Cell wall & $\begin{array}{l}\text { (Cona et al. 2006; Liszkay et al. } \\
\text { 2008) }\end{array}$ \\
\hline \multirow{5}{*}{$\begin{array}{c}\mathrm{H}_{2} \mathrm{O}_{2} \\
\text { (Hydrogen } \\
\text { peroxide) }\end{array}$} & Glycolate oxidase & Peroxisome & (Corpas et al. 2001) \\
\hline & $\begin{array}{l}\text { Fatty acid } \beta- \\
\text { oxidation }\end{array}$ & Peroxisome & (Corpas et al. 2001) \\
\hline & Oxalate oxidase & Apoplast & $\begin{array}{l}\text { (J. Dat, S. Vandenabeele, E. } \\
\text { Vranova', M. Van Montagu } \\
\text { 2000) }\end{array}$ \\
\hline & $\begin{array}{l}\text { Peroxidases, } \mathrm{Mn}^{2+} \\
\text { and } \mathrm{NADH}\end{array}$ & Cell wall & $\begin{array}{l}\text { (Grant and Loake 2000; } \\
\text { Hammond-Kosack and Jones } \\
\text { 1996) }\end{array}$ \\
\hline & Amine oxidase & Apoplast & (Allan 1997; Mittler 2002a) \\
\hline
\end{tabular}




\subsection{Exocytosis/Endocytosis in pollen tubes}

The actin cytoskeleton dynamics is important for exocytosis and cell growth in pollen tube (Kost, Spielhofer, and Chua 1998; Yan 2010). The pollen germination and tube elongation depend on exocytosis of Golgi-derived secretory vesicles in the apical zone of the pollen tube (Lord and Sandders 1992). The exocytosis taking place at the apex of the pollen tube serves to deliver the materials for the new cell wall and plasma membrane to support tip growth (Hepler et al. 2001). Mutants of exocytosis complex subunit genes in Arabidopsis show defects in pollen germination and pollen tube growth (Hala et al. 2008).

Two different kinds of endocytosis have been reported that is clathrin-independent endocytosis at the extreme tip of the pollen tube and clathrin-dependent endocytosis at the shoulder region of the pollen tube apex (Dhonukshe et al. 2007; Guan et al. 2013; Moscatelli et al. 2007). The endocytosed materials get internalized into an early endosome, after that they are sorted into different intracellular destinations like in the late endosome for degradation or are recycled back into the plasma membrane (Helling et al. 2016). Exocytosis is balanced by endocytosis via the internalization of cell wall materials, plasma membrane, and associated signalling molecules to maintain pollen tube tip growth (Guan et al. 2013; Hepler et al. 2001).

\subsection{Pulsatory and Oscillatory Growth}

Cytoplasmic streaming plays a major role in carrying organelles and vesicles to the growing tip (Graaf et al. 2005; Guan et al. 2013). Pollen tube growth kinetics is characterized by oscillatory changes in growth rate.

Several cellular parameters fluctuate at the pollen tube tip like the cytoplasmic concentration of $\mathrm{Ca}^{2+}$ and ion fluxes, actin polymerization, the thickness of the apical cell wall and local enzyme concentrations what suggested that these processes maybe interlinked (Cameron and Geitmann 2018; Holdaway, et al. 1997). F-actin levels of pollen tubes also oscillate ahead of growth oscillation, showing a relationship between F-actin polymerization and growth (Kost et al. 1998; Yan 2010). The ROP1 GTPase plays an essential role in the tip growth of pollen tubes. It is localized at the tip where its activity oscillates with the same frequency as growth. This oscillation is due to the coordinated action of two ROP1-regulated pathways: an F-actin 
assembly pathway that is in a similar phase with ROP1 activity and a delayed $\mathrm{Ca}^{2+}$ gradientforming pathway, respectively. This allows the oscillating delivery and fusion of vesicles to the plasma membrane since the former requires polymerized, the latter depolymerized actin at the tip (Cárdenas et al. 2008; Hwang et al. 2005)

\subsection{ROP GTPases}

Plants have a unique family of Rho-type small GTPases, which termed as Rho-of-plants (ROPs). ROP GTPases are member of the RAS superfamily of small GTP-binding proteins, which function as two-state molecular switches depending on their confirmation such as GDPbound (inactive form) or GTP-bound (active form) (Jurca 2011; Lundquist 2006; Wennerberg et al. 2005). The cycling of Rho proteins between active and inactive states is dependent on other regulatory proteins. The GTPase-activating proteins (GAPs) stimulate the intrinsic GTPase activity and thus increase the ratio of the GDP-bound inactive form. In contrast, guanine nucleotide exchange factors (GEFs) catalyse the exchange of GDP for GTP to activate the GTPase. Guanine nucleotide dissociation inhibitors (GDIs) block spontaneous G-protein activation and control the recycling of the GTPase between the cytosol and the cell membrane (Berken and Wittinghofer 2008).

The several studies have been done on the functional analysis on the Plant Rho GTPases (ROPs). The ROPs regulate multiple extracellular signals such as cell growth, development, cytoskeleton dynamics/reorganization and vesicular trafficking required for polarity establishment/ maintenance (including pollen tube tip growth), reproduction, and responses to the environment (Feiguelman et al 2018). Their function is exerted via the spatial and temporal activation of various downstream effector proteins (Feiguelman et al. 2018). Among these, RLCK VI_A kinases are the only known potential ROP effector kinases (Dorjgotov et al. 2009; Lajkó et al. 2018), but their link to ROP-mediated signalling pathways could not be demonstrated yet in planta.

\subsection{RLCK VI_A kinases}

In Arabidopsis, around a thousand of RLK genes have been identified (Jurca 2011; Walker and Zhang 1990). Based on the presence/absence of the extracellular domains, the RLK family 
subdivided into 46 different subfamilies. Majority of them (75\% in Arabidopsis) have aminoterminal domain; a extracellular signal perception domain, transmembrane domain, and a carboxyl-terminal kinase domain and the rest of other (25\%) have only carboxyl-terminal kinase domain but no apparent signal perception or transmembrane domains, which defined them as receptor-like cytoplasmic kinases (RLCKs).

Several functions of RLKs have been identified in a different kind of signal responses, such as pollen-pistil interaction (Kachroo et al. 2002; Liang and Zhou 2018), in hormone perception (Li and Chory 1997) disease resistance (Song et al. 1995) and in the organization of the shoot apical meristem (Clark et al 1997; Liang and Zhou 2018; Sharma, Carles, and Fletcher 2003). In few instances RLKs were shown to interact with RLCKs as downstream signalling targets. The plasma-membrane-localized M-Locus Protein kinase (MLPK) RLCK interacts with SLocus (SRK; S-Locus B-Lectin Receptor Kinase) receptor kinase to regulate selfincompatibility signalling in Brassica rapa (Kakita et al. 2007; Liang and Zhou 2018; Murase et al. 2004). In tomato, Pto kinase (RLCK) provide resistance against the pathogen Pseudomonas syringae by interacting with avirulence gene avrPto (Tang et al. 1996) The BIK1 RLCK (Botrytis Induced Kinase1) regulates the defense responses by interacting with an immune receptor kinases (Kong et al. 2016; Liang and Zhou 2018). MARIS is a member of Receptor-like cytoplasmic kinase (RLCK-VIII), and functions downstream of ANXUR1 (ANX1) and ANX2, CrRLK1L, BUDDHA'S PAPER SEAL1 (BUPS1) and BUPS2 to control pollen tip growth and pollen tube integrity (Boisson-Derniera et al. 2015; Ge et al. 2017).

RLCK-VII family member BIK1 (Botrytis-induced kinase 1) and its closest homolog PBL1 (PBS1-LIKE1) mediate the immune response in the presence of FLS2 and also other PRRs such as EFR, PEPR1, PEPR2, and LYK5 (Liang and Zhou 2018; Liu et al. 2013; Lu et al. 2010). The mutation in bikl and pbll minimized the flg22-induced responses, including calcium influx, ROS burst, callose deposition, actin filament bundling and resulted in the inhibition of seedling growth (Liu et al. 2013; Lu et al. 2010; Zhang et al. 2010).

The RLCKs based on structure are subdivided into 12 families (RLCK I to XII) which has 193 protein-coding genes (Haffani, Silva, and Goring 2004; Jurca 2011; Shiu and Bleecker 2001, 2003). However, the alignment result showed that the At RLCK VI kinase family has 14 
members belonging to two groups in Arabidopsis (Jurca et al. 2008) that the first group is RLCK VI_A (ROP-interacting) and the second group is RLCK VI_B ( ROP - non-interacting). Our group identified that the RLCK VI kinases family is directly activated by plant Rho-type (ROP) GTPases in Medicago, Arabidopsis (Molendijk et al. 2008) and Alfalfa (Dorjgotov et al. 2009). ROP1 belongs to the Rho family of small GTPases and have a key role in the regulation of tip growth in pollen tubes. The depletion or inhibition of ROP1 inhibited the pollen tube growth, however constitutively expression of active mutants of ROP1 induces growth depolarization (Gu et al. 2005; Li et al. 1999).

On the other side, very limited information is available regarding the receptor-like cytoplasmic kinases (RLCKs). The cDNA and genomic DNA sequences of the RLCK VI_A family of tobacco identification were based on the identified sequences of Arabidopsis. So we decided to focus on the functional characterization of the tobacco RLCK Class VI_A family of protein kinases during the pollen tube growth and development.

\subsection{Antisense oligodeoxynucleotide (AS-ODN) technology}

Antisense oligodeoxynucleotides (AS-ODN) are short, usually 17-22 nucleotides-long, synthetic single-stranded DNAs representing segments of the antisense strand of genomic DNA. The AS-ODNs mediate gene silencing based on two properties; first is the binding to the complementary stretches of mRNAs forming a duplex of AS-ODN/mRNA that interferes with transcription, translation, splicing and prevents polyadenylation or cap formation; and the second, susceptibility of the duplex towards cellular RNase $\mathrm{H}$, which cleaves the target mRNA while has no effect on the AS ODN (Chan, Lim, and Wong 2006; Wu et al. 2004).

AS-ODN possesses several advantages as compared to alternative technologies such as using short interfering RNAs (siRNAs) or artificial microRNAs. The plant/animal cells are able to take up the AS-ODN directly, whereas short interfering RNA (siRNAs) and artificial microRNA are usually cloned into cloning vectors to be delivered into the cell (Dinç et al. 2011; Scherer and Rossi 2003). AS-ODNs exhibit dose-dependent gene silencing and a single 
antisense AS-ODN can inhibit more than one gene of the same gene family (Dinç et al. 2011; Scherer and Rossi 2003).

The antisense oligodeoxynucleotide (AS-ODN) technology is widely used as a genomic tool for the identification of gene function since it has been discovered by Zamecnik and Stephenson in 1978 in Rous sarcoma virus for Inhibition of replication and cell transformation. In plant, first time AS-ODN was used by Tsutsumi, Kanayama, and Tano in 1992 for the Inhibition of barley alpha-amylase gene. In pollen, first time AS-ODN was used by Estruch et al. 1994 for the inhibition of calcium-dependent calmodulin-independent protein kinase in maize (Zea mays). Later on Moutinho et al. 2001 used AS-ODN for perturbation of protein function in pollen tube of Agapanthus umbellatus, Dinç et al. 2011 used for inhibition of Nucleus and Chloroplast encoded proteins of Chloroplasts in the higher plant, and Mizuta and Higashiyama 2014 for inhibition of ANX1 and ANX2 in Arabidopsis pollen tubes.

\subsection{Polyamines in pollen tube growth}

Polyamines (PAs) are small aliphatic polycationic organic molecules, containing amino groups, and are present in the cytosol and organelles. New results showed that Putrescine and Spermidine are ubiquitous in all the organisms, whereas Spermine is mainly present in eukaryotes and some bacteria (Pegg and Michael 2010). The PAs naturally occur in the cell as free as well as bound form. Their polycationic nature is due to the equal spatial distribution of total charge, which is important for their role in cell growth and development (Aloisi et al. 2016; Pegg and Casero 2011). At the physiological pH, Put, Spd and Spm or tSpm (thermospermine) have 2, 3 and 4 positive charges respectively. The polycationic nature of PAs makes them suitable to bind to cellular macromolecules such as proteins and nucleic acids having negative surfaces (Galston and Sawhney 1990; Kusano et al. 2008) through electrostatic, hydrophobic interactions (Pegg and Casero 2011) or covalent bonds (Walden, Cordeiro, and Tiburcio 1997).

PAs act as sources and scavengers of ROS and activators of antioxidant enzymes (Kusano et al. 2008; Pottosin et al. 2014; Pottosin and Shabala 2014). The PA-deficient cells accumulate ROS in the spe2 mutant of Saccharomyces cerevisiae (Chattopadhyay, Tabor, and HerbertTabor 2006), but the overexpression of Cu-Zn SOD (superoxide dismutase) reducing 
the accumulation of ROS protects these polyamine-deficient yeast cells (Balasundaram, Tabor, and Herbert 1993; Chattopadhyay et al. 2006). The PAs, the di-amine putrescine (Put), triamine spermidine (Spd) and the tetra-amine spermine (Spm) have been linked to several physiological processes in plants, such as growth and development, as well as to a vast range of biotic and abiotic stress responses (Gémes et al. 2016, 2017; Moschou, Paschalidis, et al. 2008; Wu et al. 2010). Moreover, $\mathrm{H}_{2} \mathrm{O}_{2}$, formed during PA catabolism itself act as a secondary messenger by activating several important signal molecules such as $\mathrm{Ca}^{2+}$ and nitric oxide (NO) (Quan et al. 2008; Wendehenne, Durner, and Klessig 2004) which indicates some overlapping physiological roles of PAS and these second messengers in plants (Tanou et al. 2014; Yamasaki and Cohen 2006).

Furthermore, exogenous PAs were shown to strongly affect pollen germination, maturation and pollen tube elongation (Aloisi et al. 2016; Singh and Tandon 2012). There are also reports about the influence of the polyamine biosynthesis inhibitor methylglyoxal-bis (guanylhydrazone) (MGBG) on pollen germination and pollen tube growth in Prunus mume L. (Wolukau et al. 2004) and C. roseus L. (Prakash et al. 1988). Despite the number of studies about the role of PAs in pollen germination and growth, it is still largely unclear by which mechanisms PAs take part in the regulation of these processes. 


\section{CHAPTER 3: AIMS}

3.1 One of the aims of the present work was to investigate if PAs, reactive oxygen species (ROS), and nitric oxide (NO) are interconnected in the process of pollen germination and tipgrowth.

* To identify the effects of exogenous polyamines (Put, Spd and Spm) on pollen germination and tube growth.

* To investigate how the inhibition of ROS production or ROS treatment effect the action of PAs on pollens/pollen tubes.

* To investigate how the application of NO scavengers or NO donors affect the germination/growth of polyamine-treated pollens.

3.2 Another aim of our work was to evaluate the function of the ROP-activated RLCK Class VI group A family protein kinases in pollen tube growth. It was supposed that these kinases should function in a similar way as ROP GTPases in the regulation of polar cell growth.

To identify the members of the tobacco (Nicotiana tabacum) RLCK VI_A family

* To identify those RLCK VI_A genes of tobacco that are expressed in the pollen

* Designing and synthesis of antisense oligodeoxynucleotides (AS-ODNs) against the selected tobacco RLCK VI_A kinases.

* To investigate pollen tube growth and morphology in relation to the application of the synthesized AS-ODNs to pollen tubes 


\section{CHAPTER 4: MATERIALS AND METHODS}

\subsection{Plant material, pollen germination and growth condition}

Mature pollen was collected from tobacco plants (Nicotiana tabacum, SR1) and germinated in germination media containing 1,61 $\mathrm{mM} \mathrm{H}_{3} \mathrm{BO}_{3}, 1 \mathrm{mM} \mathrm{CaCl}_{2}, 1 \mathrm{mM} \mathrm{Ca}\left(\mathrm{NO}_{3}\right)_{2}, 1 \mathrm{mM} \mathrm{MgSO}$, 10\% sucrose, pH 6 (Lee et al. 2008; Wang and Jiang 2011). To monitor the effect of different polyamines on pollen germination and tube growth, $10 \mu \mathrm{M}$ of Put, Spd or Spm, respectively, were added to the germination media for 4 hours at $28^{\circ} \mathrm{C}$ (Bezvoda et al. 2014). To determine the mean tube length, at least 50 randomly selected pollen tubes were measured in each of three replicates. Similar sampling strategy was used to study the pollen germination rate. Pollen grains were considered as germinated if the tube length was greater than the diameter of the grain.

\subsection{In situ detection of nitric oxide and reactive oxygen species}

After pollen grains were incubated in germination media with or without different PAs at $28^{\circ} \mathrm{C}$ for 4 hours, samples were suspended in $10 \mu \mathrm{M}$ NO-specific fluorescent probe, 4-amino-5methylamino-2', 7'-difluorofluorescein diacetate (DAF-FM DA, Abcam, Cambridge) for 30 min in darkness at room temperature and then the excess fluorophore was washed out with Tris-HCl buffer (10 mM, pH 7.4) (Feigl et al. 2013). DAF-FM DA responds to NO donors and/or scavengers but not to hydrogen peroxide or peroxynitrite that is why it is considered as a NO specific fluorescent probe (Kolbert et al. 2015). For in situ detection of ROS, 2, 7dichlorodihydro-fluorescein diacetate (H2DC-FDA, Sigma-Aldrich, St. Louis, MO) was applied. Pollens were incubated in $10 \mu \mathrm{M}$ H2DC-FDA solubilized in 2-N-morpholineethansulphonic acid/potassium chloride $(\mathrm{MES} / \mathrm{KCl}) \mathrm{pH} 6.15$ for $15 \mathrm{~min}$ at $37^{\circ} \mathrm{C}$ in darkness. After staining, pollens were washed once with a dye-free buffer and the fluorescence of the oxidized product of H2DC-FDA, dichlorofluorescein (DCF), was visualized by a fluorescent microscope. To induce ROS production, $\mathrm{H}_{2} \mathrm{O}_{2}(0.5 \mathrm{mM}$, AnalaR, NORMAPUR) was used. As ROS scavenger N,N'-Dimethylthiourea (DMTU, $5 \mathrm{mM}$ ) was applied. NO specificity was assayed using $200 \mu \mathrm{M}$ of the NO scavenger 2-(4-carboxyphenyl)-4, 4, 5, 5tetramethylimidazoline-1-oxyl-3-oxide (cPTIO, Enzo Life Sciences, Inc) or $100 \mu \mathrm{M}$ of the NO donor S-Nitros-N-acetyl-D,L-penicillamines (SNAP, Enzo Life Sciences). 


\subsection{Isolation of mRNA and cDNA synthesis}

For the gene expression analysis in tobacco, total RNA was isolated from pollens and leaves by using the Dynabeads Oligo (dT) 25 magnetic mRNA isolation system according to the manufacturer's instruction (Life Technologies as part of ThermoFisher Scientific, Waltham, MA USA). The cDNA was synthesized by using ThermoFisher Scientific's RevertAid cDNA Synthesis Kit.

\subsection{BLAST search}

A genome-wide homology search of RLCK VI_A genes was performed by using nucleotide BLAST search (Basic Local Alignment Search Tool; http://blast.ncbi.nlm.nih.gov/) using oneby-one the known sequences of Arabidopsis thaliana RLCK VI_A members as query and restricting the search for Nicotiana tabacum sequences. Alignment of the predicted amino acid sequences of the Arabidopsis and Tobacco kinases was made and a similarity tree was generated by the CLUSTAL OMEGA tool (https://www.ebi.ac.uk/Tools/msa/clustalo/). The Tobacco kinases were named after their closet Arabidopsis homologues.

\subsection{Cloning and sequencing of PCR amplified Nicotiana tabacum kinase sequences}

Total mRNAs were isolated from pollens of Nicotiana tabacum SR1 and converted to cDNA as described above. PCR primers (given below in Table 2) were planned (Primer BLAST; https://www.ncbi.nlm.nih.gov/tools/primer-blast/) using the Nicotiana tabacum sequences obtained by the BLAST search as query (see above). PCR fragments were obtained using the proofreading PHUSION II polymerase according to the manufacturer's instructions (ThermoFischer Scientific). The amplified cDNA fragments were purified after gel electrophoretic separation and then ligated into the pBluescript II KS (+) vector (Stratagene, La Jolla, CA, USA) and sequenced by using a BigDye v3.1 kit (Applied Biosystems, Foster City, CA, USA). 
Table 2: Primers used for the RT-PCR analysis.

\begin{tabular}{|c|c|c|}
\hline Name & Sequence & Length \\
\hline NtVI_A1 Fw & 5'-ACATCGCGATATCAAAGCCT-3' & 20-mer \\
\hline NtVI_A1 Rev & 5'-TCCCTTAACAAAAGGCTAACACA-3' & 23-mer \\
\hline NtVI_A2 Fw & 5'-TGGGCACTTAGCACCAGAAT-3' & 20-mer \\
\hline NtVI_A2 Rev & 5'-ACATGGAAGTTCAACCTCAAAA-3' & 22-mer \\
\hline NtVI_A3 Fw & 5'-GGACTTGCAAAGTGGTTGCC-3' & 20-mer \\
\hline NtVI_A3 Rev & 5'-AACAATGTCGTAGGCATCGC-3' & 20-mer \\
\hline NtVI_A4 Fw & 5'-GGTGGTCTGCACCTTGTTCT-3' & 20-mer \\
\hline NtVI_A4 Rev & 5'-ATGGGTTCGTTCTCGCCTTT-3' & 20-mer \\
\hline NtVI_5 Rev & 5'-GACGTACGTACCACCAGAGTC-3' & 21-mer \\
\hline NtVI_A5 Fw & 5'-TCACAGCAAAGCCTCGTCAT-3' & 20-mer \\
\hline NtVI_A6 Fw & 5'-GTGGGCAAGTTTGAAGGCAC-3' & 20-mer \\
\hline NtVI_A6Rev & 5'-AAATAGTTTCGGCAGCGGGT-3' & 20-mer \\
\hline NtVI_A7 FW & 5'-TCGGAATTCTAGTACATGTTGACC-3' & 24-mer \\
\hline NtVI_A7 Rev & 5'-GGTTTGGCCCACATCACAAC-3' & 20-mer \\
\hline
\end{tabular}

\subsection{The parameters for AS-ODN designing}

The efficiency of AS-ODN depends on accurate prediction of mRNA secondary structure because AS-ODN binds to open regions of target mRNA. So the selection of potential ASODN is a very important step in the antisense technology (Stein 2001). There are different parameters that have to be considered to design potent AS-ODNs such as the secondary structure of RNA, preferably the local secondary structures, the sequence motif, GC content, and binding energy (G37) (Chan et al. 2006b; Chanda and Dave 2009).

\subsection{Prediction of the secondary structure of mRNA}

Secondary structure of mRNA was selected based on the computational algorithms which are freely available in the public domain such as the mfold and sfold programs. The $m$ fold program (http://www.bioinfo.rpi.edu/applications/ mfold) predicts all possible optimal and suboptimal structures of mRNA, overall minimal free energy and possible folding (Zuker 2003). The sfold program (http://sfold.wardsworth.org/index.pl) predicts the best secondary structure of mRNA (Ding, Chan, and Lawrence 2004). The combination of both $m$ fold and sfold, helps to determine overall free energy and the most commonly occurring secondary structure of a given mRNA. The locally conserved secondary structure of an mRNA which showed hairpin/duplex formation were not considered for AS-ODNs designing. 


\subsection{Motif search for AS-ODN synthesis}

Matveeva et al. in 2000 analysed more than 1000 motif for AS-ODN activity. The analysis for motifs sequence search were based on the results of pulished data on oligonucleotides studied. They used the program Oligostat (program was created in combination with Microsoft Excel) for database analysis They found that the presence of 5'-GTGG-3', 5'-TGG-3', 5'-GGG-3', 5'AGGG-3', 5'-GGGG-3', 5'-GAGT-3', 5'-GGGA-3', 5'-TGGG-3', 5'-GGAT-3', 5'-GGTG-3', 5'TGGC-3', 5'-GAG-3', 5'-ATGC-3', 5'-TGGT-3', 5'-GAT-3', 5'-GTG-3', 5'-GATG-3', 5'-GGA$3^{\prime}, 5^{\prime}$-GGT-3' and 5'-AGAG-3' motifs in the AS-ODNs showed enhance the activity of ASODN mediated mRNA knockdown whereas, the presence of 5'-CCCC-3', 5'-CCC-3', 5'TTTA-3', 5'-CAGT-3', 5'-TTTC-3',5'-AGCC-3', 5'-CCCA-3', 5'-ATTT-3', 5'-TTAT-3', 5'TATT-3', 5'-CCGG-3', 5'-TCC-3', 5'-CCAG-3', 5'-TAT-35'-CAG-3', 5'-TTT-3', 5'-CTCC-3', and 5'-TTA-3' motifs in AS-ODNs, weakened AS-ODN activity (Chan et al 2006; Freier et al. 2004; Matveeva et al. 2000).

Total GC content determines the thermodynamic stability of the AS-ODN-mRNA duplexes and cellular RNase $\mathrm{H}$ activity. The strong effects of AS-ODN were observed when the $\mathrm{G}$ or $\mathrm{C}$ number was minimum of 11 residue in 20 bps, whereas only poor inhibition occurred if the $G$ or $C$ the number was 9 or less than 9 (Chan et al. 2006; Freier et al. 2004). The binding energy between AS-ODN molecules should be $\Delta \mathrm{G}_{37}^{\circ} \geq-1.1 \mathrm{kcal} / \mathrm{mol}$, whereas binding energy between the AS-ODN and mRNA should be $\Delta \mathrm{G}_{37}^{\circ} \geq-8 \mathrm{kcal} / \mathrm{mol}$ to get potent AS ODN (Matveeva et al. 2000).

\subsection{Designing of AS-ODNs}

The cloned and sequenced regions of the Nt RLCK VI_A (Nt RLCK VI_A3, Nt RLCK VI_A4, Nt RLCK VI_A6, and Nt RLCK VI_A7) cDNAs were selected for AS-ODN designing. The AS-ODNs were designed by the oligo5 program (W. Rychlick, National Bioscience Inc., Plymouth, MN, USA). All AS-ODN were 17-22 nucleotides long. 


\subsection{Synthesis of AS-ODNs}

The chemical synthesis of the AS-ODNs was performed in the "Nucleic Acid Synthesis Laboratory", Biological Research Center, Hungarian Academy of Science, Szeged, Hungary) using a DNA/RNA/LNA H-16 synthesizer (K\&A Laborgeraete) by standard $\beta$-cyanoethyl phosphoramidite chemistry at a nominal scale of $0.2 \mu \mathrm{mol}$. The reagents for the automated ASODN synthesis were from Sigma-Aldrich (https://www.sigmaaldrich.com). The AS-ODNs were purified on Poly-PAK cartridges (Glen Research, Sterling, VA) yielding 97\% full-sized AS-ODNs as shown by analytical ion exchange HPLC. Phosphorothioates were built in with $>98 \%$ efficiency by using TEDT (Tetraethylthiuram disulfide) sulphurizing reagent. HPLC purification was used to reduce nonspecific cytotoxicity in the cell.

\subsection{Chemical modifications of AS-ODNs}

To provide stability to the AS-ODNs is an important step towards successful application. ASODNs otherwise easily get degraded by all types of cellular nucleases of the host organism (Kurreck 2003). Possible sites for chemical modification of nucleic acids are the base, sugar, and inter nucleotide linkage. The chemical modifications increases resistance against nuclease degradation, leads to higher bioavailability and also helps the uptake of AS-ODNs (Chan et al. 2006a; Kurreck 2003; Smith and Jain 2019).

In plants, phosphorothioate modifications were frequently used to enhance nuclease resistance of AS-ODNs. In the phosphorothioate chemical modification (belongs to the first generation of chemical modifications of ODNs) one of the non-bridging oxygen atoms is replaced by sulphur in the phosphodiester bond. In each AS-ODNs, three bases at each end were synthesized with phosphorothioate backbone (Bezvoda et al. 2014). This is the most commonly used chemical modification for gene silencing studies in vivo and in vitro (Eckstein 2000).

Finally, the homology searches of designed AS-ODN with the available database in Genbank were performed using BLAST (http://blast.ncbi.nlm.nih.gov/Blast.cgi) search to avoid significant homology to any other gene in the Nicotiana tabacum genome 


\subsection{Delivery of AS-ODNs into growing pollen tubes}

The cellular uptake of AS-ODN mainly occurs through an adsorptive endocytosis process but unmodified AS-ODN which possesses net negative charge are unable to cross the plasma membrane. The liquid media (mentioned above) were used to grow pollen in the wells of 24well microplates. Pollens (Nicotiana tabacum, SR1) were cultured in the liquid media along with the AS-ODNs having 30 $\mu \mathrm{m}$ concentrations (Mizuta and Higashiyama 2014; Potocký et al. 2007). Pollens were cultured in a moisture chamber placed into an incubator at $28^{\circ} \mathrm{C}$ for 4 hours (Bezvoda et al. 2014). Three independent experiments were performed. Pollen tube growth was observed by light microscopy.

\subsection{Microscopic observation and statistical analysis}

To detect fluorescence intensity, a Zeiss Axiovert 200 M-type fluorescent microscope (Carl Zeiss, Germany) equipped with a high-resolution digital camera (Axiocam HR) was used. The fluorescence intensity was analysed by the Axiovision Rel. 4.8 software using filter set 10 (excitation occurred at 450-490 $\mathrm{nm}$ and emission was detected at 515-565 nm). The same camera settings were used for each digital image. The relative fluorescence intensities of at least fifty pollen tubes in each of three replicates were used for analysis by the Image $\mathrm{J}$ software and mean relative fluorescence intensities were calculated.

Bright field imaging was performed with Olympus Cell-R microscope for pollen germination analyses. Objectives used during imaging were $4 \mathrm{X}$ (pollen germination analyses) and 10X (pollen tube length measurements and identification of pollen abnormalities). ImageJ (http://rsbweb.nih.gov/ij/) was used for the quantitative analysis. The graphic analysis was performed by the GraphPad Prism version 6 (GraphPad Software, La Jolla California USA, www.graphpad.com).

Statistical analysis was performed by SIGMAPLOT12.0 statistical software. Quantitative data are presented as the mean $\pm \mathrm{SE}$ and the significance of the difference between sets of data was determined by one-way analysis of variance (ANOVA) following Duncan's multiple range tests; a $\mathrm{P}$ value of less than 0.05 was considered significant. 


\section{CHAPTER 5: RESULTS}

\subsection{Effect of exogenous polyamines on the growth of pollen tubes}

\subsubsection{The various polyamines affect tobacco pollen grain germination dependent mainly on the level of ROS but not NO}

The effects of the three polyamines Put, Spm, and Spd on the germination rate of tobacco pollens were different if applied at the same $10 \mu \mathrm{M}$ concentration. While Put and Spd increased, Spm decreased pollen germination rate compared to the untreated controls (Fig. 1A and $\mathrm{B})$.

$\mathbf{A}$

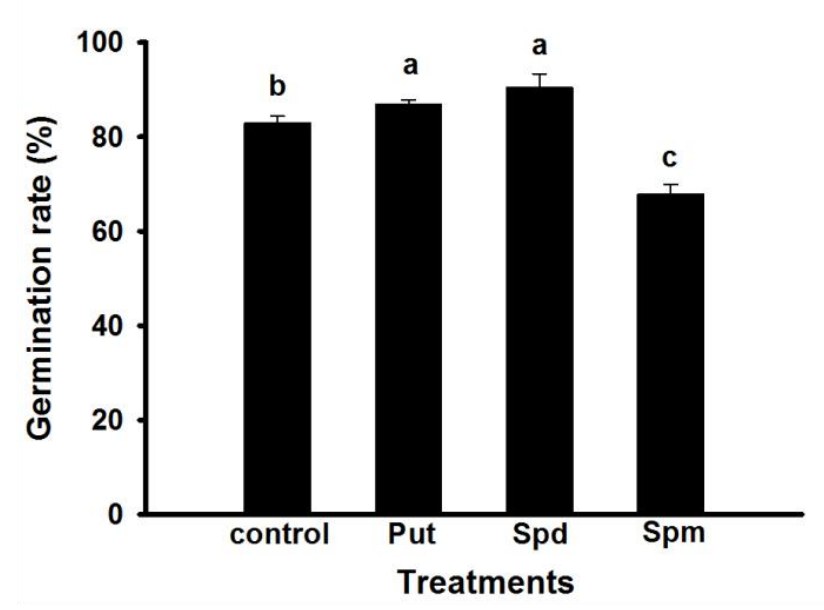

B

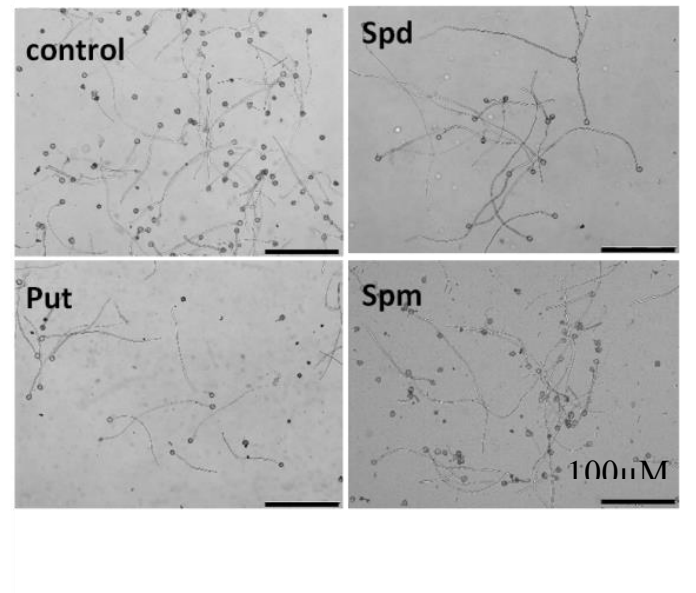

Figure 1: Germination rate in Put, Spd and Spm treated pollens, respectively. (A) The three polyamines Put, Spm, and Spd on the germination rate of tobacco pollens were different if applied at the same $10 \mu \mathrm{M}$ concentration. While Put and Spd increased, Spm decreased pollen germination rate compared to the untreated controls. (B) These are indicating pollen germination. Data are means \pm SE of three biological replicates with five technical replicates each. Different letters indicate significant differences of Duncan's multiple comparisons $(\mathrm{P}<0.05)$.

ROS are essential for pollen germination (Potocký et al. 2007), while in several studies, NO had an inhibitory effect on it (He et al. 2007; Jimenez-Quesada et al. 2017). To examine whether in the case of tobacco pollen, exogenous polyamines affected the germination rate through regulation of ROS and/or NO accumulation, the levels of these compounds were investigated in the treated pollen grains. None of the three polyamine treatments caused 
detectable changes in NO level (Fig. 2A). In contrast, Put and Spd decreased, but Spm increased ROS levels in pollen grains compared to the controls (Fig. 2B).

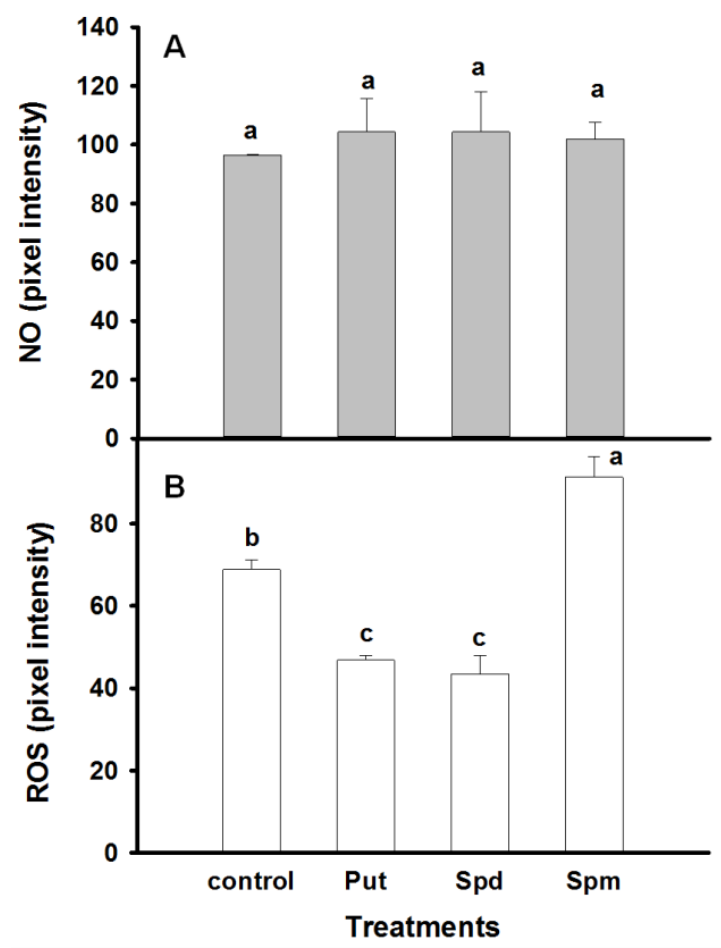

Figure 2: Polyamine induced NO and ROS production in germinated pollen grains. None of the three polyamine treatments caused detectable changes in NO level (Fig. 2A). In contrast, Put and Spd decreased, but Spm increased ROS levels in pollen grains compared to the controls (Fig. 2B). Data are means \pm SE of three biological replicates with fifty pollen $(n=50)$ were used for the measurements. Different letters indicate significant differences of Duncan's multiple comparisons $(\mathrm{P}<0.05)$.

Since Put and Spd increased germination rate and Spm inhibited it, a correlation could be established between the action of the various PAs and the ROS accumulation. It was further strengthened by experiments where the co-application of Spm with the ROS scavenger DMTU reduced ROS production and increased the pollen germination rate as compared to the only Spm-treated pollens (Fig. 3A and 3B). 

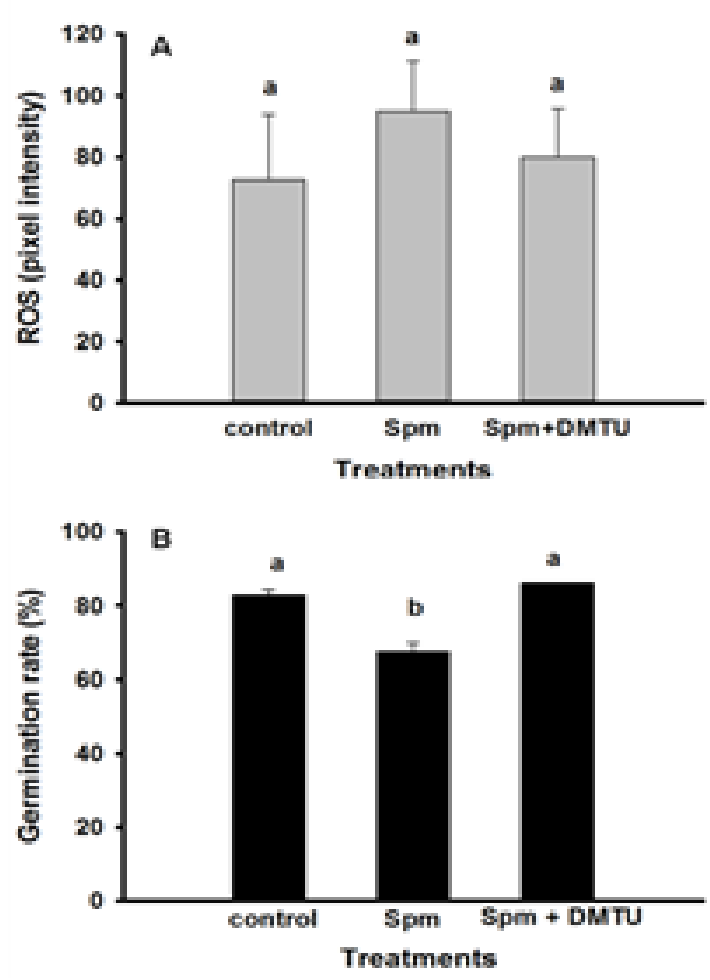

Figure 3: Effect of DMTU on germination rate in Spm treated tobacco pollens. (A) Inhibitory effect of DMTU on ROS production in Spm treated germinated pollen grains. The co-application of Spm with the ROS scavenger DMTU reduced ROS production. (B) Co-application of Spm and DMTU increased the pollen germination rate as compared to the only Spm-treated pollens. Data are means \pm SE of three biological replicates with fifty pollen $(n=50)$ were used for the measurements. Different letters indicate significant differences of Duncan's multiple comparisons $(\mathrm{P}<0.05)$.

Our data therefore suggest that polyamines differentially affect pollen germination according to their influence on the ROS, but not the NO level of tobacco pollen. The evolving localization of ROS and NO, accumulating first in the tip region than in the whole length of the tube, was observed during cucumber pollen germination (Sírová et al. 2011). It has been reported that exogenous PAs modulate ROS-producing/scavenging enzymes during the apical growth of pear pollen tube (Aloisi et al. 2015) and thus may also influence ROS metabolism during germination. One can hypothesize that during the in vitro germination of tobacco pollen, exogenous Put and Spd may decrease stress-related ROS production 
maintaining the proper ROS homeostasis for germination while Spm evokes excess ROS (Aloisi et al. 2015) disturbing the regulated ROS accumulation/distribution.

\subsubsection{Exogenous polyamines affect tobacco pollen tube growth differentially altering the relative NO/ROS ratio}

The effect of the exogenously applied polyamines on tobacco pollen tube elongation was also investigated. Among the three polyamines, each at $10 \mu \mathrm{M}, \mathrm{Spm}$ had no effect on the pollen tube length, while Spd enhanced, but Put decreased pollen tube elongation compared to the control (Fig. 4A and B).

A

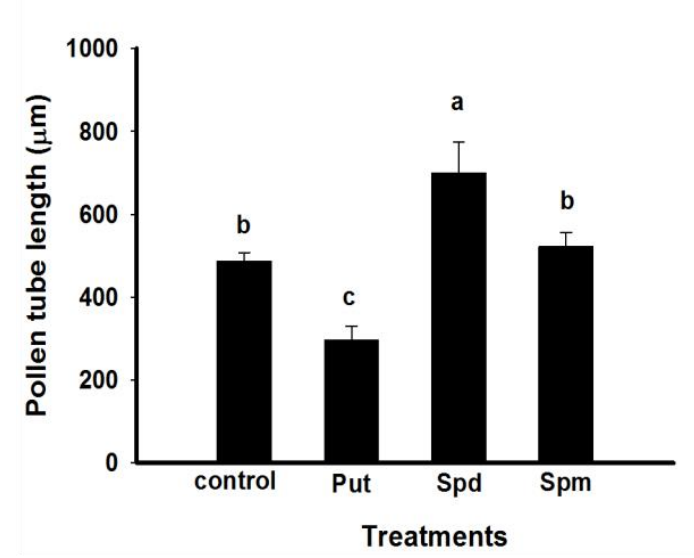

$B$

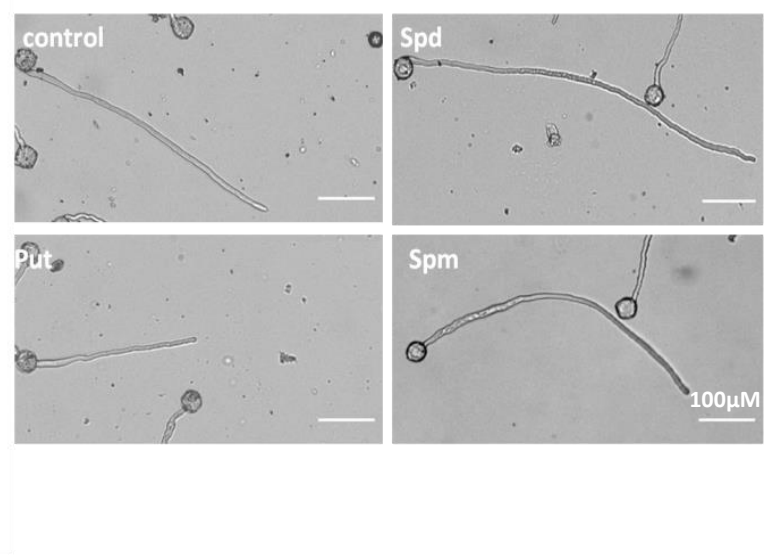

Figure 4: Changes in pollen tube length treated with different polyamines (Put, Spd, Spm). (A) Among the three polyamines, each at $10 \mu \mathrm{M}$, Spm had no effect on the pollen tube length, while Spd enhanced, but Put decreased pollen tube elongation compared to the control. (B) These are indicating pollen germination.Data are means $\pm \mathrm{SE}$ of three biological replicates with fifty pollen $(n=50)$ were used for the measurements. Different letters indicate significant differences of Duncan's multiple comparisons $(\mathrm{P}<0.05)$.

PAs have been shown to control (promote or inhibit) pollen tube elongation in other systems in a dose-dependent manner (Sorkheh et al. 2011). In Pyrus communis pollen tubes, the three polyamines were also reported to differentially affect pollen tube growth: Spm decreased tube length app. by $50 \%$ at $10 \mu \mathrm{M}$, while Spd and Put inhibited the growth only at much higher concentrations (Aloisi et al. 2015). The difference between these observations might be related to the dissimilarity in the investigated species and/or in the time of application; we directly germinated the pollen grains in the presence of the PAs while Aloisi and co-workers applied 
the PAs one hour after putting the grains into the germination medium. Considering the level of ROS and NO levels in growing pollen tubes, the NO level could be well correlated with the measured pollen tube length: Put decreased, but Spd increased NO production while Spm did not have a significant effect on it (Fig. 5A and B).
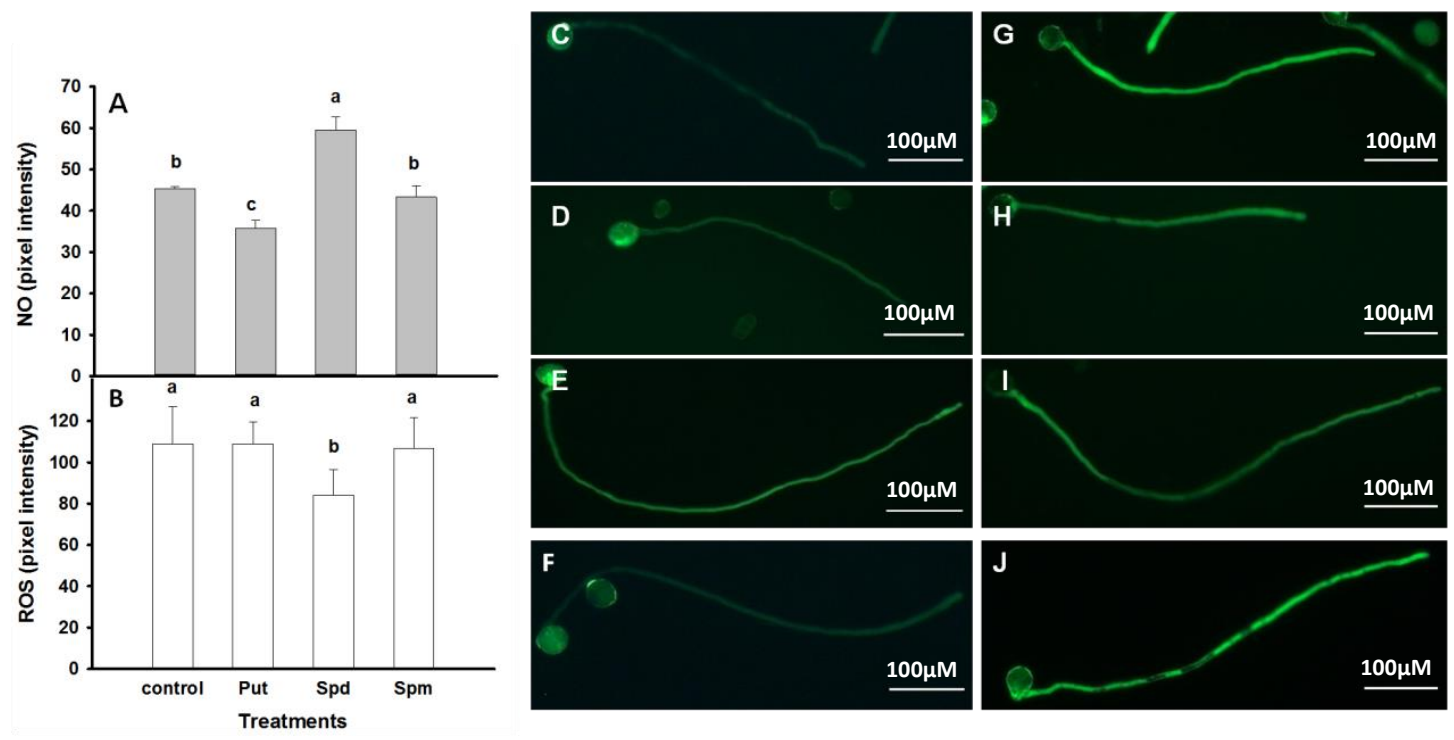

Figure 5: Considering the level of ROS and NO levels in growing pollen tubes. (A) The NO level could be well correlated with the measured pollen tube length; Put decreased, but Spd increased NO production while Spm did not have a significant effect on it. (B) The Put and Spm did not alter the ROS level of pollen tubes but the Spd treatment reduced it significantly in comparison to the untreated controls. NO (A; C-F) and ROS (B; G-J) production in control $(\mathrm{C}, \mathrm{G})$ Put $(\mathrm{D}, \mathrm{H}), \mathrm{Spd}(\mathrm{E}, \mathrm{I})$ and $\mathrm{Spm}(\mathrm{F}, \mathrm{J})$ treated pollen tubes, respectively, after four hours treatment. Data are means $\pm \mathrm{SE}$ of three biological replicates with fifty technical replicates each. Different letters indicate significant differences of Duncan's multiple comparisons $(\mathrm{P}<0.05)$.

We also observed that Put and Spm did not alter the ROS level of pollen tubes but the Spd treatment reduced it significantly in comparison to the untreated controls (Fig. 5B). To investigate that the observed changes in NO and/or ROS levels only correlates with or are the cause of the observed pollen tube growth phenotypes, the NO and ROS levels were manipulated in the polyamine treated pollen tubes. The NO-donor SNAP resulted in 
NO accumulation and complemented the negative effect of Put on pollen tube length without altering the ROS level (Fig. $6 \mathrm{~A}$ and B).
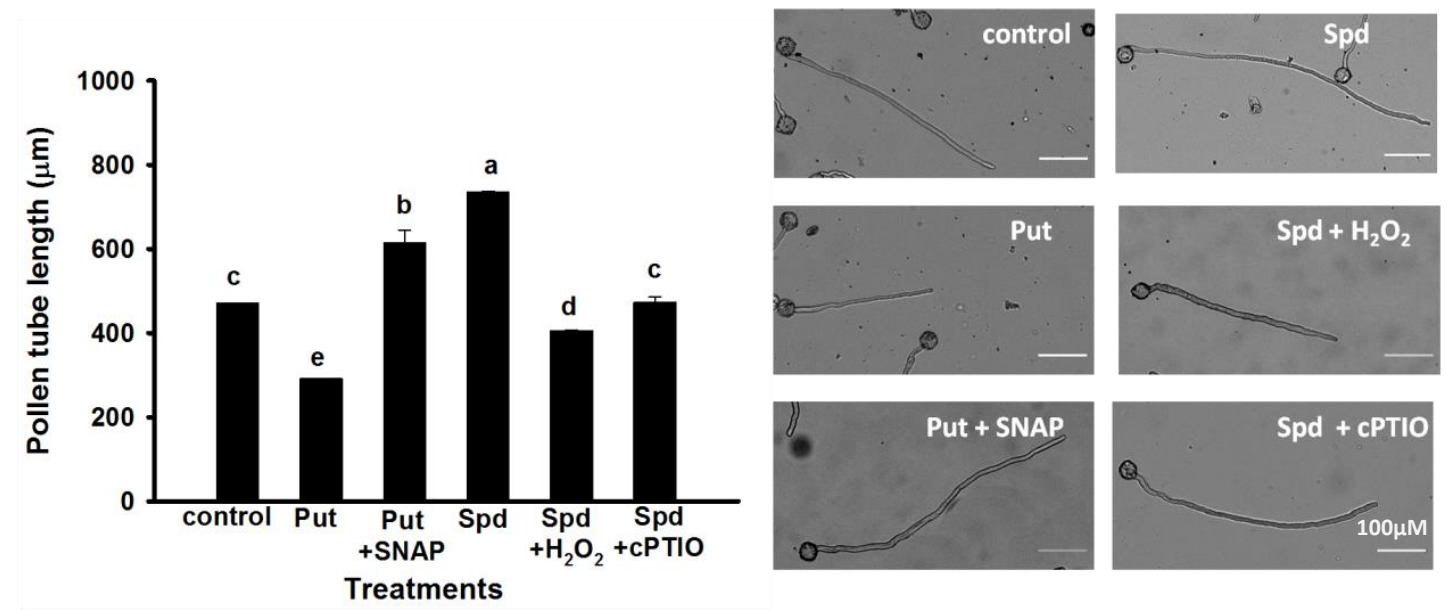

Figure 6: Effect of SNAP (NO donor), cPTIO (NO scavenger) and $\mathrm{H}_{2} \mathrm{O}_{2}$ on pollen tube length in polyamine treated pollens. (A) The NO-donor SNAP resulted in NO accumulation and complemented the negative effect of Put on pollen tube length without altering the ROS level. (B) These are indicating pollen tube length.Data are means $\pm \mathrm{SE}$ of three biological replicates with fifty technical replicates each. Different letters indicate significant differences of Duncan's multiple comparisons $(\mathrm{P}<0.05)$.

Effect of SNAP (NO donor), cPTIO (NO scavenger) and $\mathrm{H}_{2} \mathrm{O}_{2}$ on NO (A; C-H) and ROS (B; I-N) production in control and polyamine treated pollen tubes. (Fig 7 A) When Put was treated with SNAP (NO donor) it increased NO level whereas with cPTIO (NO scavenger) reduced the NO level. (Fig 7 B) When Spd was treated with $\mathrm{H}_{2} \mathrm{O}_{2}$ it increased ROS level whereas with cPTIO (NO scavenger) reduced the ROS level. 

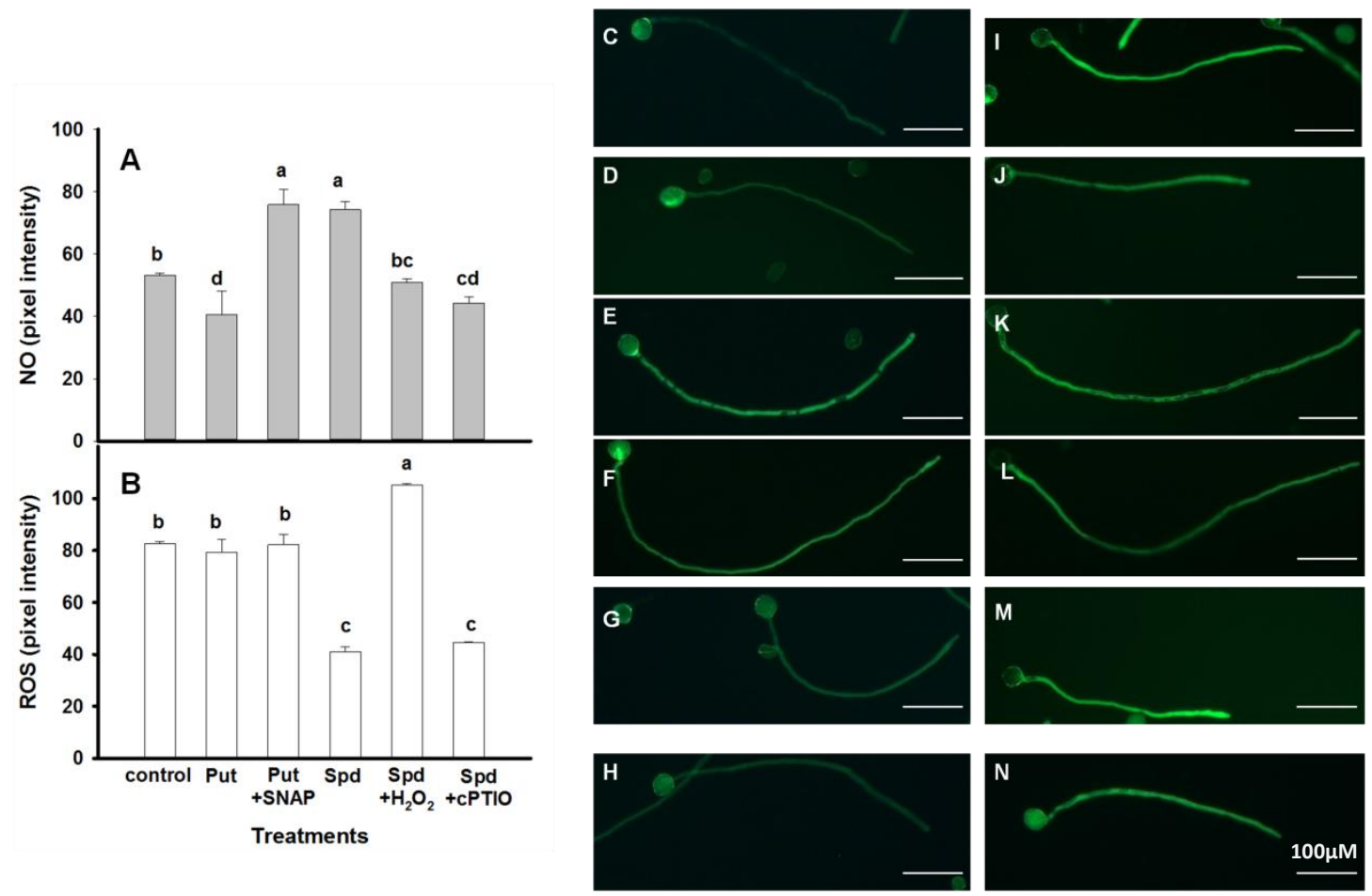

Figure 7: Effect of SNAP (NO donor), cPTIO (NO scavenger) and $\mathrm{H}_{2} \mathrm{O}_{2}$ on NO (A; C-H) and ROS (B; I-N) production in control and polyamine treated pollen tubes. (A) When Put was treated with SNAP (NO donor) it increased NO level whereas with cPTIO (NO scavenger) reduced the NO level. (B) When Spd was treated with $\mathrm{H}_{2} \mathrm{O}_{2}$ it increased ROS level whereas with cPTIO (NO scavenger) reduced the ROS level. (A, I: control; D, J: Put treated pollens; E, K: Put+SNAP treated pollens; F, L: Spd treated pollens; G, M: $\mathrm{Spd}+\mathrm{H}_{2} \mathrm{O}_{2}$ treated pollens; $\mathrm{H}, \mathrm{N}$ : Spd+cPTIO treated pollens). Data are means $\pm \mathrm{SE}$ of three biological replicates with fifty technical replicates each. Different letters indicate significant differences of Duncan's multiple comparisons $(\mathrm{P}<0.05)$.

In Spd-treated pollen tubes, the NO scavenger cPTIO reduced the accumulation of NO and thus inhibited the positive effect of the treatment on pollen tube growth without affecting the ROS level (Fig. 6-7). Interestingly, ROS accumulation due to exogenous $\mathrm{H}_{2} \mathrm{O}_{2}$ application reduced the endogenous NO level and concomitantly pollen tube length in Spdtreated pollen tubes in comparison to controls (Fig.6-7). These observations indicate that a high NO/low ROS ratio promotes while the opposite inhibits tobacco pollen tube growth and polyamines differentially affect this ratio primarily via decreasing (Put) or increasing 
(Spd) the NO level. These results are somewhat in contrast with previous studies in which the negative regulatory role of NO (He et al. 2007; Jimenez-Quesada et al. 2017; Pasqualini et al. 2015; Prado et al. 2004; Pradoa et al. 2008) and positive role of ROS (Kaya et al. 2014) in pollen tube growth have been reported. This contradiction might be explained by differences in the endogenous

NO and ROS are strongly interconnected and their dose-dependent cellular effects are also inter-reliant (Hancock and Neill 2019). Exogenous PAs may co-ordinately regulate both endogenous NO and ROS levels since they are known to induce ROS (Moschou and Roubelakis-angelakis 2014) as well as NO (Tun et al. 2006) production or to serve as ROS scavengers (Aloisi et al. 2015). In our experiments, the relatively low exogenous PA concentrations $(10 \mu \mathrm{M})$ might only fine tune the NO/ROS ratio in comparison to other harsher treatments (e.g. direct exogenous application of NO or ROS).

\subsection{The role of RLCK VI_A family kinases in pollen tube growth and polarity 5.2.1 Identification of Nicotiana tabacum RLCK VI_A kinase cDNA sequences}

A genome-wide nucleotide sequence homology search was performed by BLAST using the known cDNA sequences of Arabidopsis RLCK VI_A family members as queries. The parameters were used to limit the search for Nicotiana tabacum sequences. Alignment of the predicted amino acid sequences of the Arabidopsis and tobacco kinases was made using the CLUSTAL OMEGA tool (https://www.ebi.ac.uk/Tools/msa/clustalo/). The result of homology search is shown below (Fig 8). Based on the sequence comparison a similarity tree of Arabidopsis thaliana and Nicotiana tabacum RLCK VI_A sequences was generated (Fig. 9) and the tobacco kinases were named after their closest Arabidopsis homologues. 


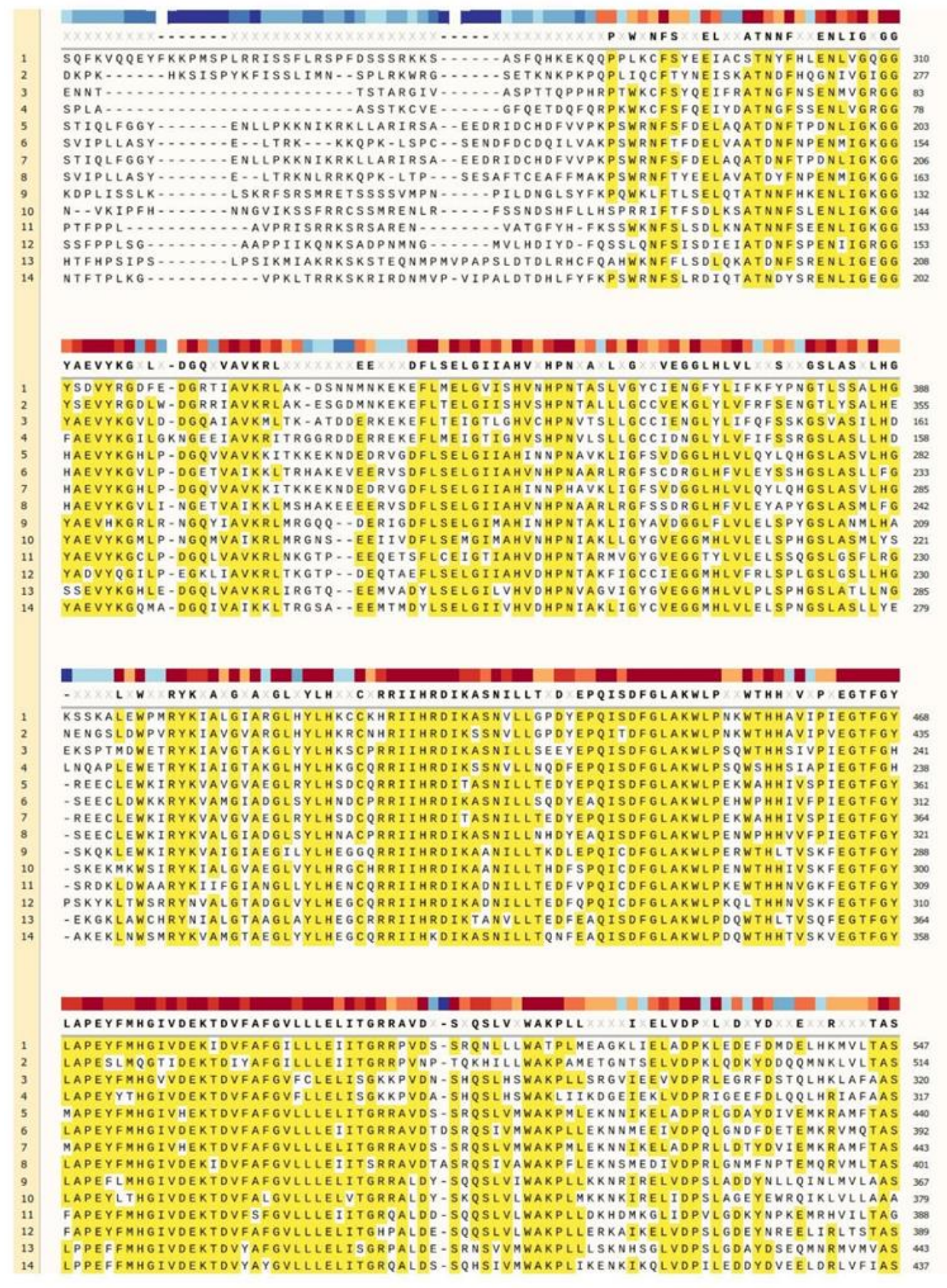

Figure 8: Part of the multiple sequence alignment comparison of Arabidopsis and Nicotiana tabacum RLCK VI_A cDNA sequences. The comparison of the most conserved kinase domains sequences are shown. 1,3,5,7,9,11,13 are the Arabidopsis RLCK VI_A sequences (from 1 to 7); 2,4,6,8,10,12,14 are the Nicotiana RLCK VI_A sequences (from 1-7). Conserved amino acids ( $>50 \%$ ) have a yellow background. 


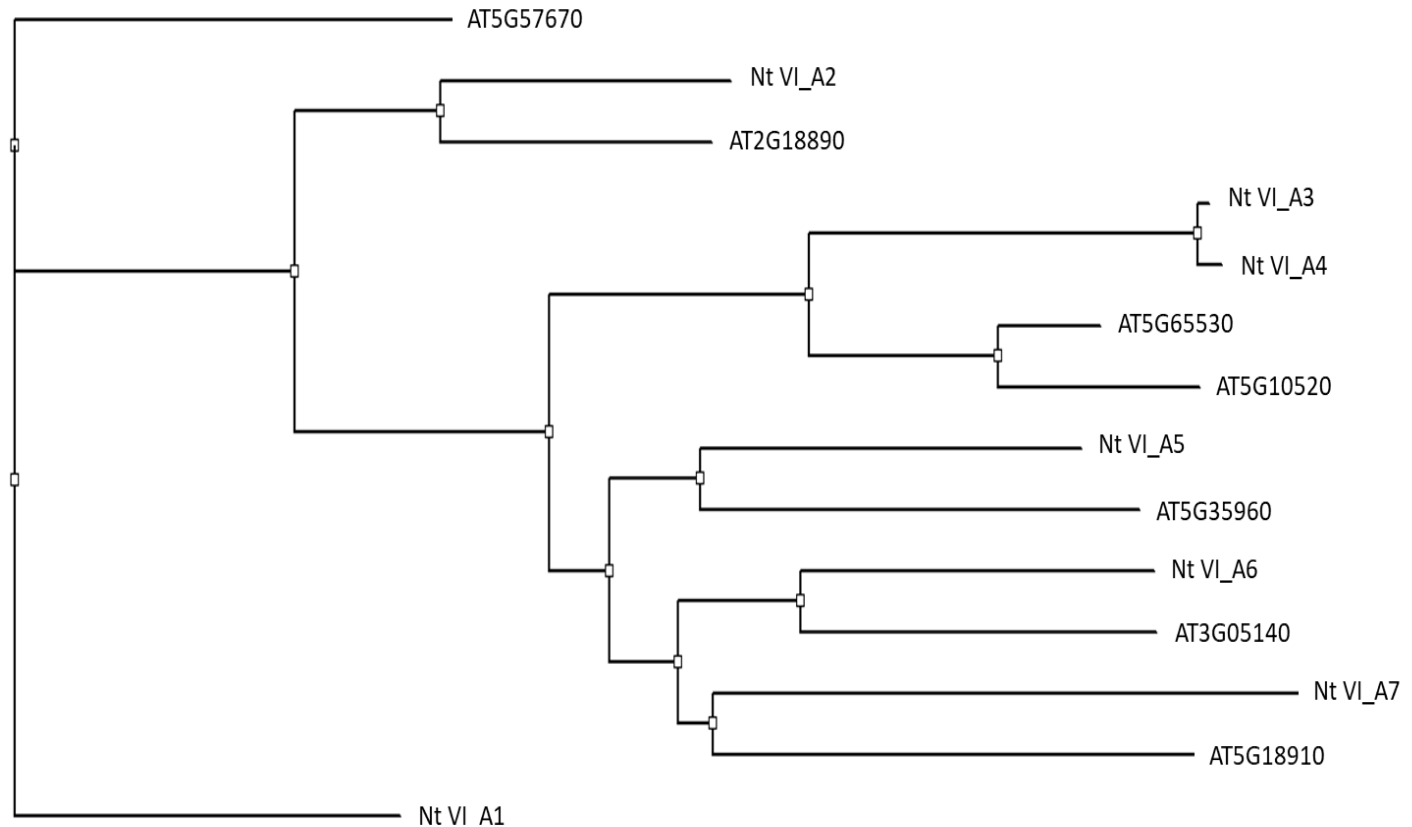

Figure 9: The similarity tree showing the relationships of RLCK VI_A sequences of Nicotiana tabacum and Arabidopsis thaliana. The Nicotiana tabacum kinases were named after their closest homologue of Arabidopsis thaliana.

\subsubsection{Gene expression analysis of Nt RLCK VI_A in pollen and leaves of Nicotiana tabacum} Specific PCR primers were planned and synthesized for all Nicotiana tabacum RLCK VI_A kinase cDNAs (given above in table 2).

The total RNA was isolated from the pollens and leaves of Nicotiana tabacum and then converted into cDNA. The gene expression analysis of RLCK VI_A genes was performed by RT PCR. The RLCK VI_A genes of Nicotiana tabacum showed variation in the level of gene expression (Fig. 10). While the Nt RLCK VI_A1, Nt RLCK VI_A2, and Nt RLCK VI_A5 (hardly visible), genes showed stronger expression in the leaf than in the pollen, all the others, namely Nt RLCK VI_A3, Nt RLCK VI_A4, Nt RLCK VI_A6, and Nt RLCK VI_A7 showed stronger expression in pollen than in the leaves (Fig 10). 

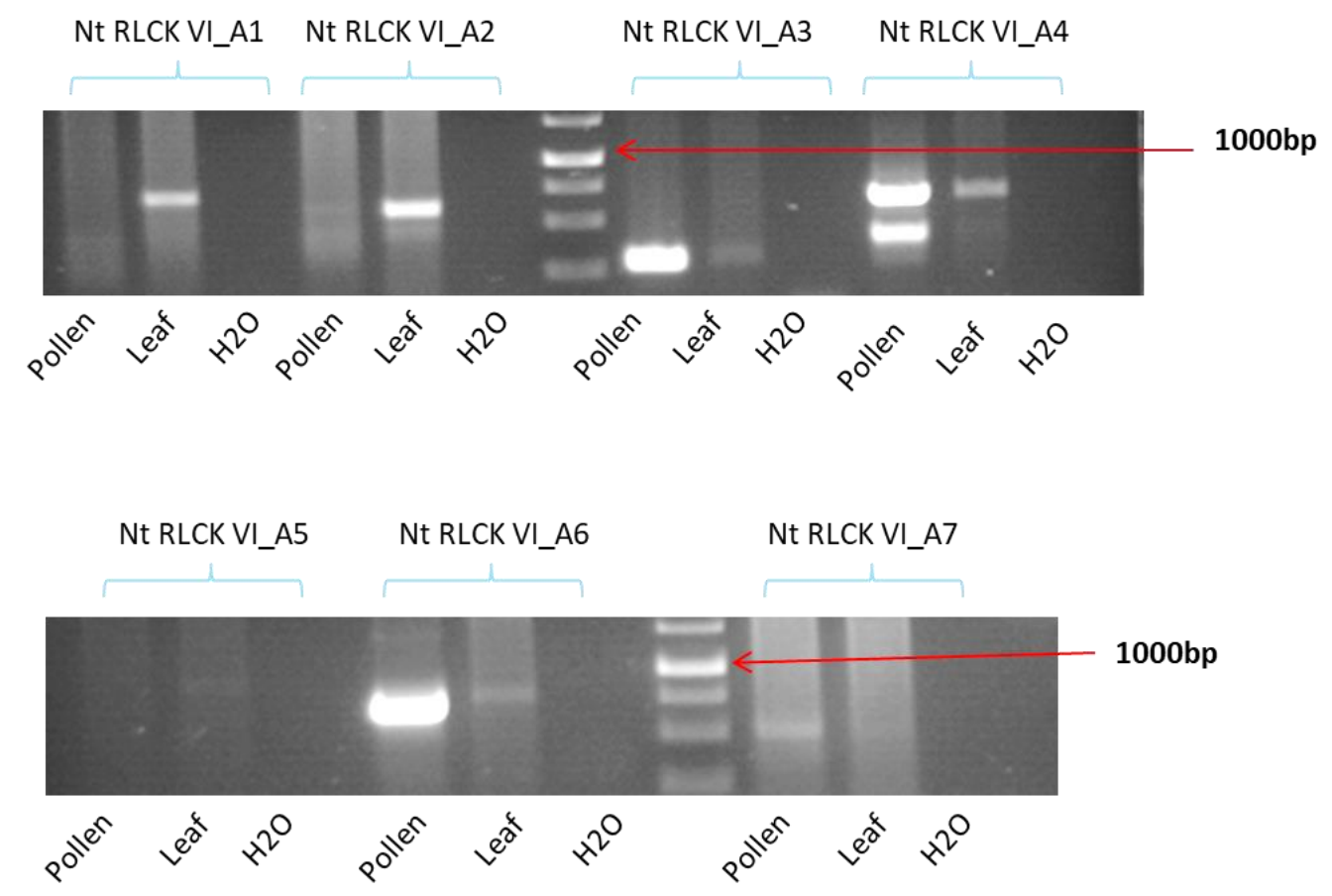

Figure 10: The expression pattern of the seven RLCK VI_A genes in Nicotiana tabacum as determined by RT PCR.

\subsubsection{Verification of Nicotiana tabacum RLCK VI_A sequences before the AS-ODN design}

For the designing of specific AS-ODNs, we wanted to know the exact DNA sequences of the RLCK VI_A kinases from the same Nicotiana tabacum genotype that was used for the pollen tube growth experiments since it is different from the genotypes that provided most of the database sequences. Therefore, we isolated and sequenced PCR-generated cDNA fragments of all pollen-expressed RLCK VI_A kinases (Nt RLCK VI_A3, Nt RLCK VI_A4, Nt RLCK VI_A6, and Nt RLCK VI_A7) of the SR1 genotype. Sequences of these specific regions were used for designing the AS-ODNs. The designed primers were (given below in table 3 )

\subsubsection{Designing of AS-ODNs}

Based on the sequencing results, we planned AS-ODNs against Nt RLCK VI_A3, Nt RLCK VI_A4, Nt RLCK VI_A6, and Nt RLCK VI_A7 fragments to specifically silence the expression of these pollen-expressed Nt RLCK VI_A genes. 
The oligo5 program (W. Rychlick, National Bioscience Inc., Plymouth, MN, USA) was used for the AS-ODNs design. AS-ODNs length was set between 17-22-nucleotides. An example of AS-ODN designing is shown on Fig 11.

Table 3: The designed primers were

\begin{tabular}{|l|l|l|}
\hline \multicolumn{1}{|c|}{ Name } & \multicolumn{1}{|c|}{ Sequence } & \multicolumn{1}{c|}{ Length } \\
\hline A3 BamHI FW & 5'-GGACTTGCAAAGTGGTTGCC-3' $^{\prime}$ & 20 -mer \\
\hline A3 Xbal Rev & 5'-tttctagaTAACGAGCTGCATATGACGA-3' $^{\prime}$ & 29 -mer \\
\hline A4 BamHI FW & 5'-GGTGGTCTGCACCTTGTTCT-3' $^{\prime}$ & 20 -mer \\
\hline A4 Xbal Rev & 5'-tttctagaTACTCCATAACGAGCTGCAT-3' & 29-mer \\
\hline A6 BamHI FW & 5'-ttggatccATTGGCAAAGGAGGGTATGCT-3' & 29-mer \\
\hline A6 Xbal Rev & 5'-tttctagaTGTCGAGTTGTACTCGGCTG-3' & 29-mer \\
\hline A7 BamHI FW & 5'-TCGGAATTCTAGTACATGTTGACC-3' & 24-mer \\
\hline A7 Xbal Rev & 5'-ttttctagaCACTGCCTGATTTTGCTGG-3' & 28-mer \\
\hline
\end{tabular}




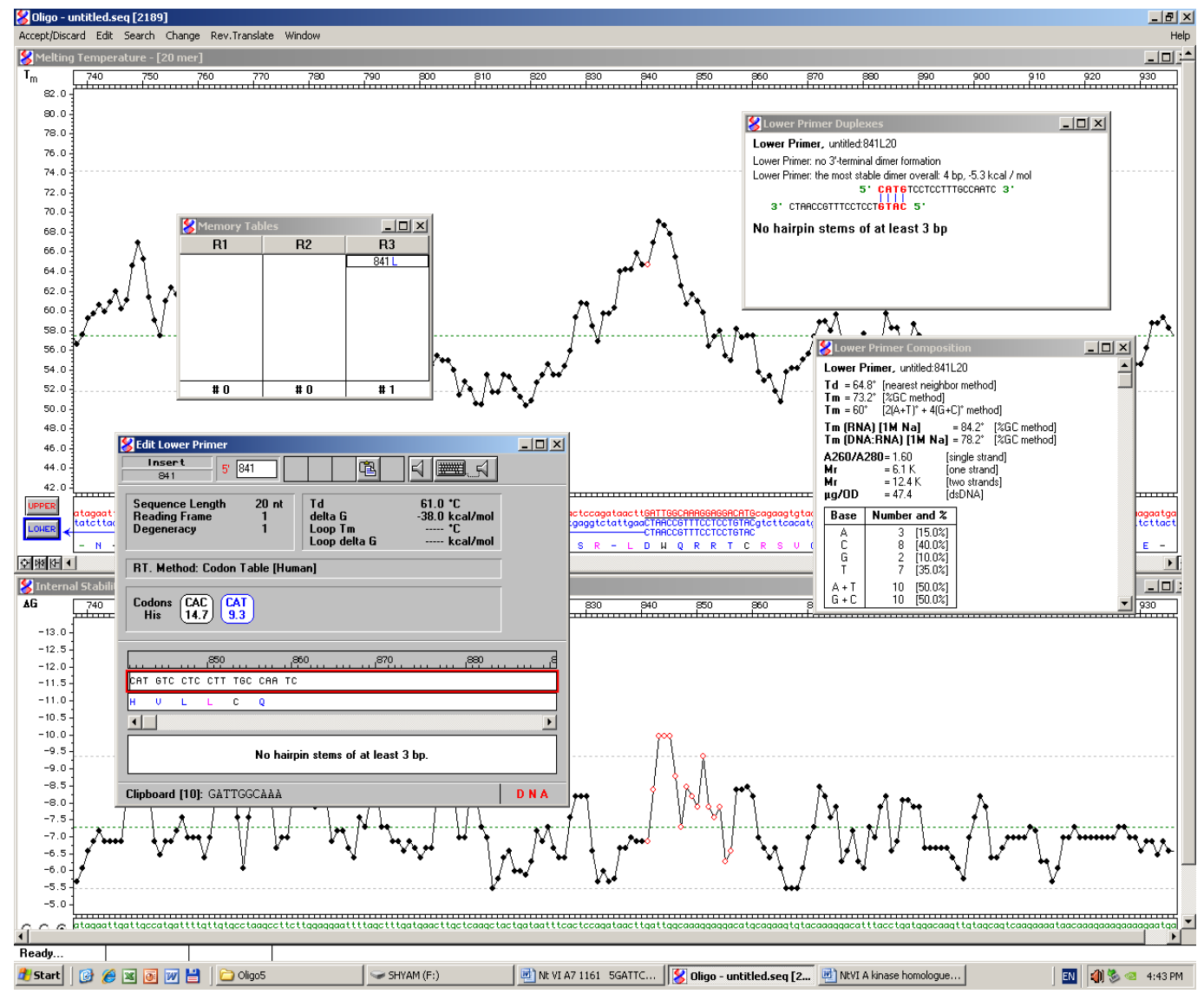

Figure 11: Analysis of tobacco RLCK VI_A3 for AS-ODN designing using the oligo5 program.

It is well known that the efficiency of AS-ODN depends on accurate prediction of the secondary structure of mRNA as well as on the nucleotide sequence of the oligo. The possible secondary structure of tobacco RLCK VI_A mRNA sequences was determined by the mfold software. The structure of RLCK VI_A3 is given as an example (Fig. 12. A). In addition, a motif search was carried out to define oligo sequences that can be efficient in mRNA binding and silencing (Fig. 12. B; as an example). Combination of the results was used to determine the best target sequence for designing an AS-ODN (Fig. 12). Finally, homology searches were performed using the selected sequence to detect any significant homology of the designed ASODN with other tobacco mRNAs. If any designed AS-ODNs showed significant homology to any other gene it was discarded. 
(A)

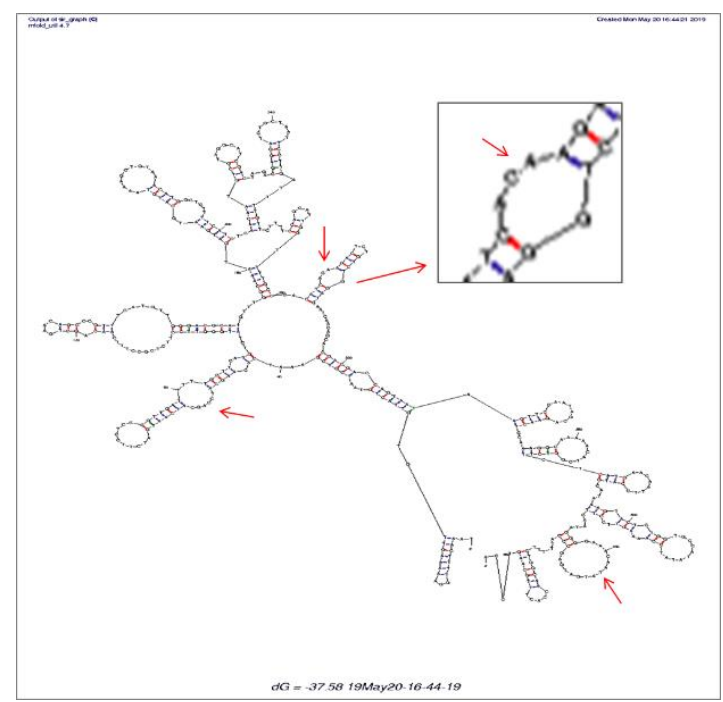

(B)

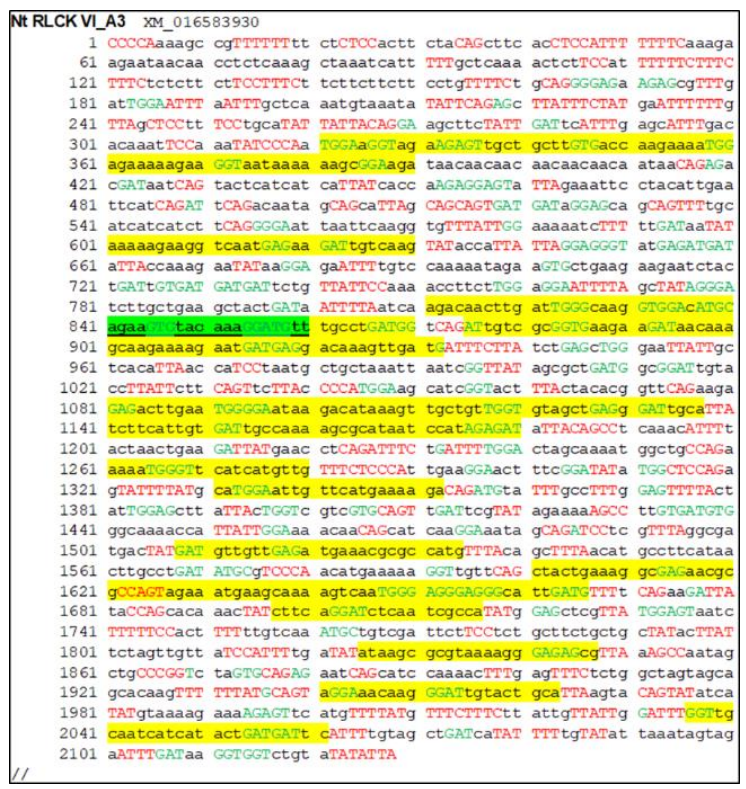

Figure 12: Different parameter search for AS-ODN designing. (A) Possible secondary structure of RLCK VI_A3 of tobacco mRNA created with the help of mfold program (Zuker 2003). The arrows are indicating potential target sites for AS-ODNs. (B) The motif search results. Sequence motifs marked with green color letters indicate stronger AS-ODN effect; red color letters indicate weaker AS-ODN effect. Light green color backgrounds highlight the selected sequence for designing an AS-ODN against RLCK VI_A3 of tobacco. 


\subsubsection{Synthesis of AS/S-ODNs}

The chemical synthesis of the AS-ODNs was performed against Nt RLCK VI_A3, Nt RLCK VI_A4, Nt RLCK VI_A6, and Nt RLCK VI_A7 in the "Nucleic Acid Synthesis Laboratory", Biological Research Center, Hungarian Academy of Science, Szeged, Hungary.

The list of AS-ODNs which were used in this work for the gene silencing are Nt RLCK VI_ A3.1 AS (841L20mer); 5'catGTCCTCCTTTGCCAatc3', A4.2 AS (1127L21mer); 5' ctcCAACTGCCACTTTATatc3', A6.1AS (1411L17mer); 5'catCGGTTTTCTCAtcc3', A7.2AS (1007L21mer) 5'cccTCCTTCA ACTCCATAtcc3'. 841L20mer; L- Indicates left side (L) of AS-ODN is the 841 position whereas 20mer- indicates the length of nucleotide.

The complementary sequences of AS-ODNs of Nt RLCK VI_A mRNA sequence used as a negative control, e.g. Nt RLCK VI_A3.1 S (20mer) 5'gtaCAGGAGGAAACGGTtag3' and A7.2S (21mer) 5' gggAGGAAGTTGAGGTA Tagg3'. To provide stability enhancing nuclease resistance to the AS-ODNs phosphorothioate (PS) chemical modification was used (Fig. 13).

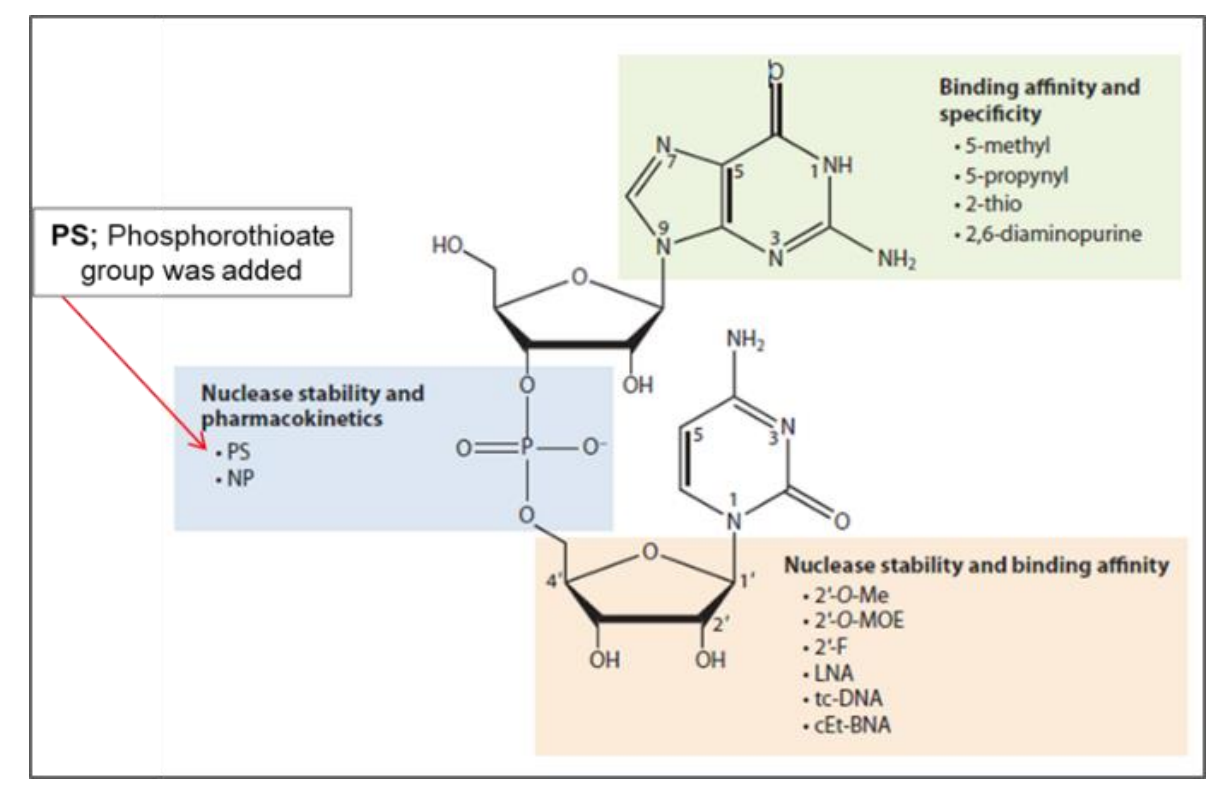

Figure 13: Possible sites for chemical modification of nucleic acids are base, sugar, and inter nucleotide linkage. In our case we used phosphorothioate (PS) for the chemical modification. Abbreviations: 2_-F, 2_fluoro; 2_- $O$-Me, 2_- $O$-methyl; 2_- $O$-MOE, 2_- $O$-methoxyethyl; cEt-BNA, constrained ethyl BNA; NP, N3_-phosphoramidate; PS, phosphorothioate; LNA, locked nucleic acid; tc-DNA, tricyclo-DNA. The image is taken from Smith and Jain 2019. 


\subsubsection{Effect of AS-ODN treatment on Nicotiana tabacum pollen}

The silencing of Nt RLCK VI_A members like Nt RLCK VI_A3, Nt RLCK VI_A4, Nt RLCK VI_A6, and Nt RLCK VI_A7 were done one-by-one. It was observed that the silencing of Nt RLCK VI_A3, 4, 6 and 7 lead to the increased rate of various abnormalities, like formation of branches, knots, or widening, sometimes even bubble-like, tips of the pollen tubes (Fig-s 1416.) These abnormalities occurred in response to AS-ODNs of all investigated Nt RLCK VI_A genes. In the case of control (without any treatment) and S-ODNs (sense strand; control) altogether less than $2 \%$ abnormalities were registered, whereas in the case of AS-ODN treatments 14 to $18 \%$ abnormalities were observed. Most of these abnormalities were branching (10-16\%; Fig. 14.) followed by knot formation (6-10\%; Fig. 15.) and widening tips (3-7\%, Fig. 16.). All these abnormalities indicate polarity establishment defects. It was also observed that the abnormal pollen tubes were always shorter (Fig. 17.).

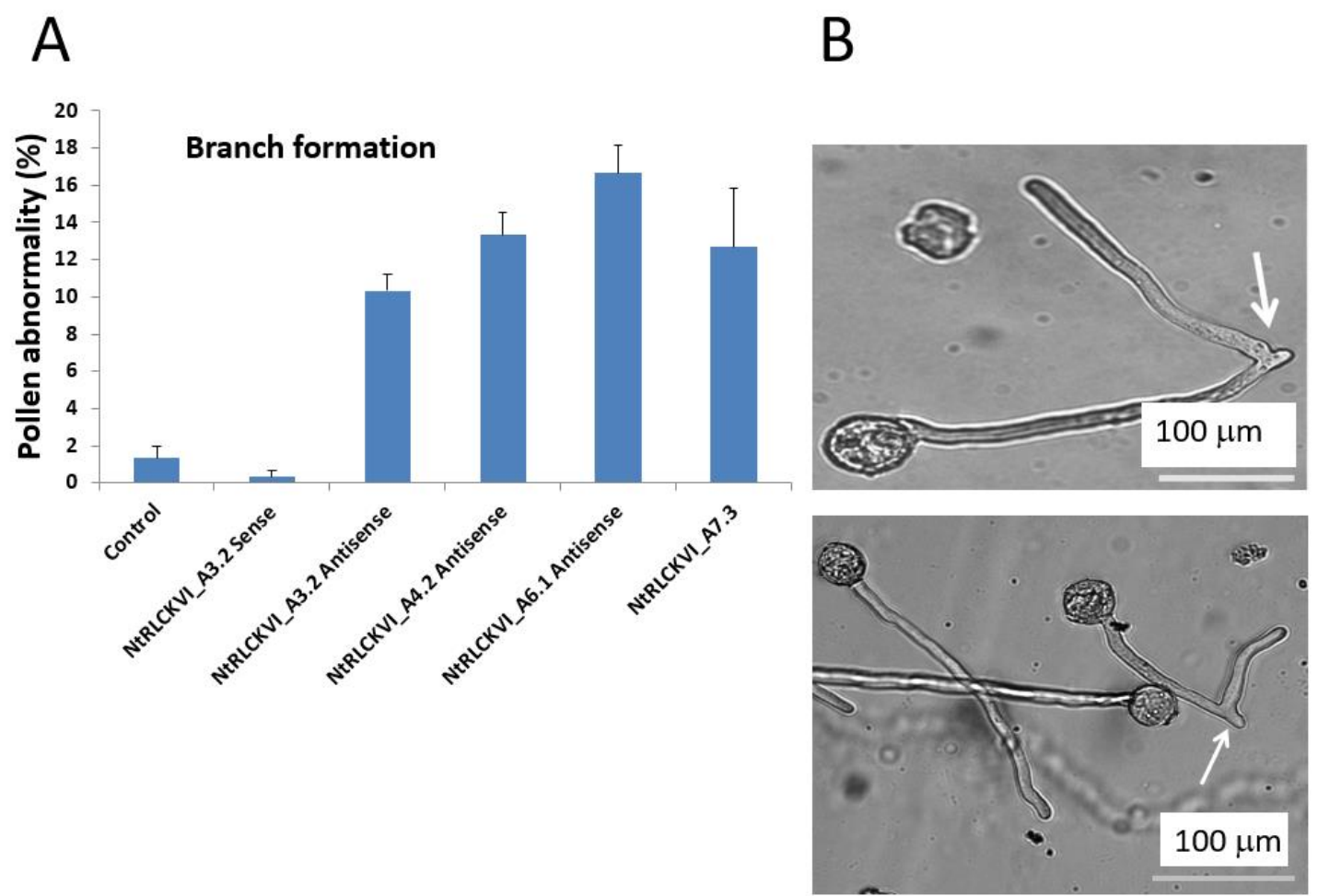

Figure 14: The effect of AS/S-ODNs on the rate of pollen tube branching. A) The ASODN treatments targeting Nt RLCK VI_A3, 4, 6 and 7 caused increased rate of abnormalities as compared to untreated or S-ODN-treated controls. Data are means \pm SE of sixty pollen tubes each. B) Examples of abnormalities that were observed. 
A B

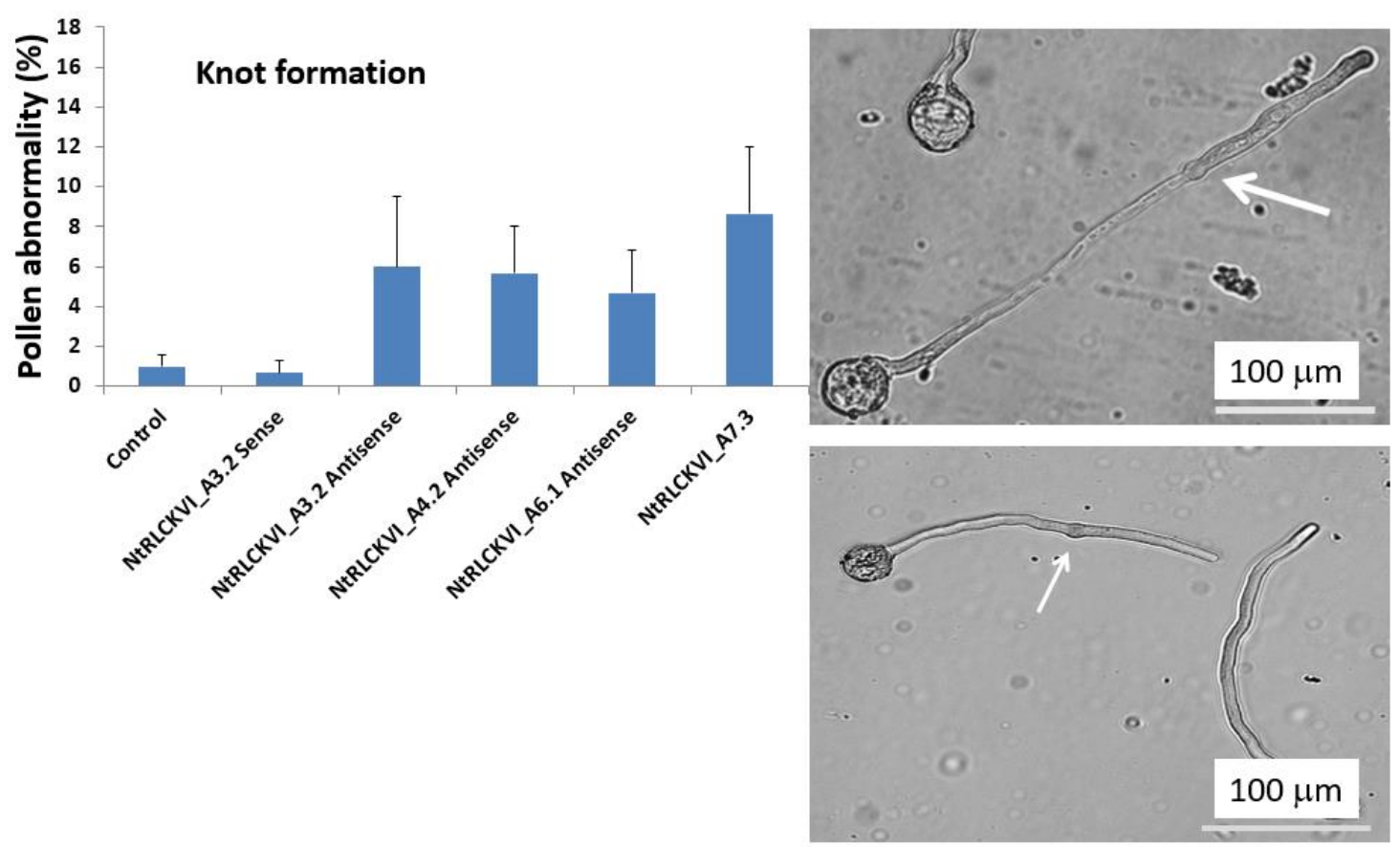

Figure 15: The effect of AS/S-ODNs on the rate of knot appearance on pollen tubes. A) The AS-ODN treatments targeting Nt RLCK VI_A3, 4, 6 and 7 caused increased rate of abnormalities as compared to untreated or S-ODN-treated controls. Data are means $\pm \mathrm{SE}$ of sixty pollen tubes each. B) Examples of abnormalities that were observed. 


\section{A}

B
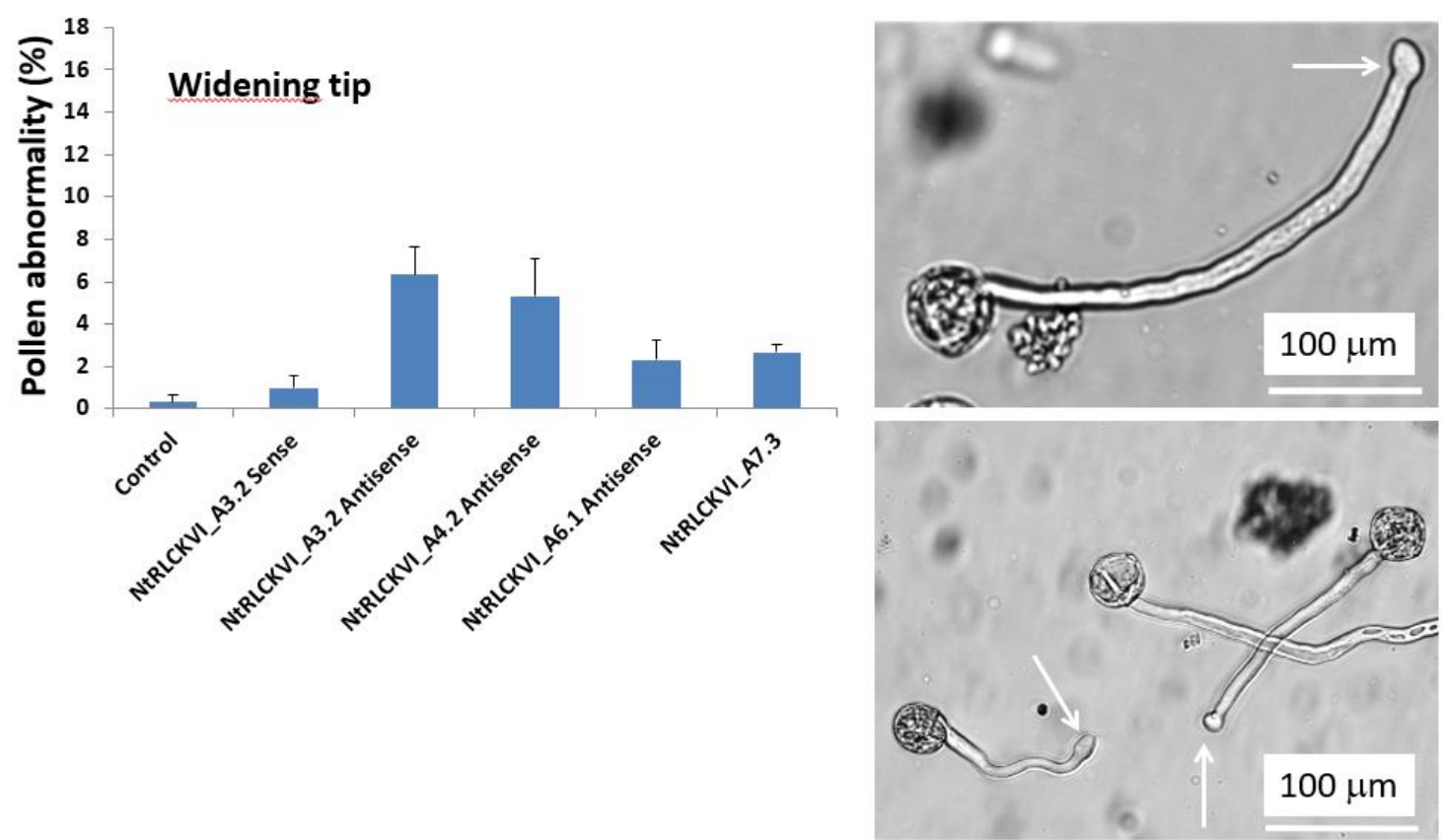

Figure 16: The effect of AS/S-ODNs on the rate of pollen tube tip widening including bubble-like tips. A) The AS-ODN treatments targeting Nt RLCK VI_A3, 4, 6 and 7 caused increased rate of abnormalities as compared to untreated or S-ODN-treated controls. Data are means \pm SE of sixty pollen tubes each. B) Examples of abnormalities that were observed. 


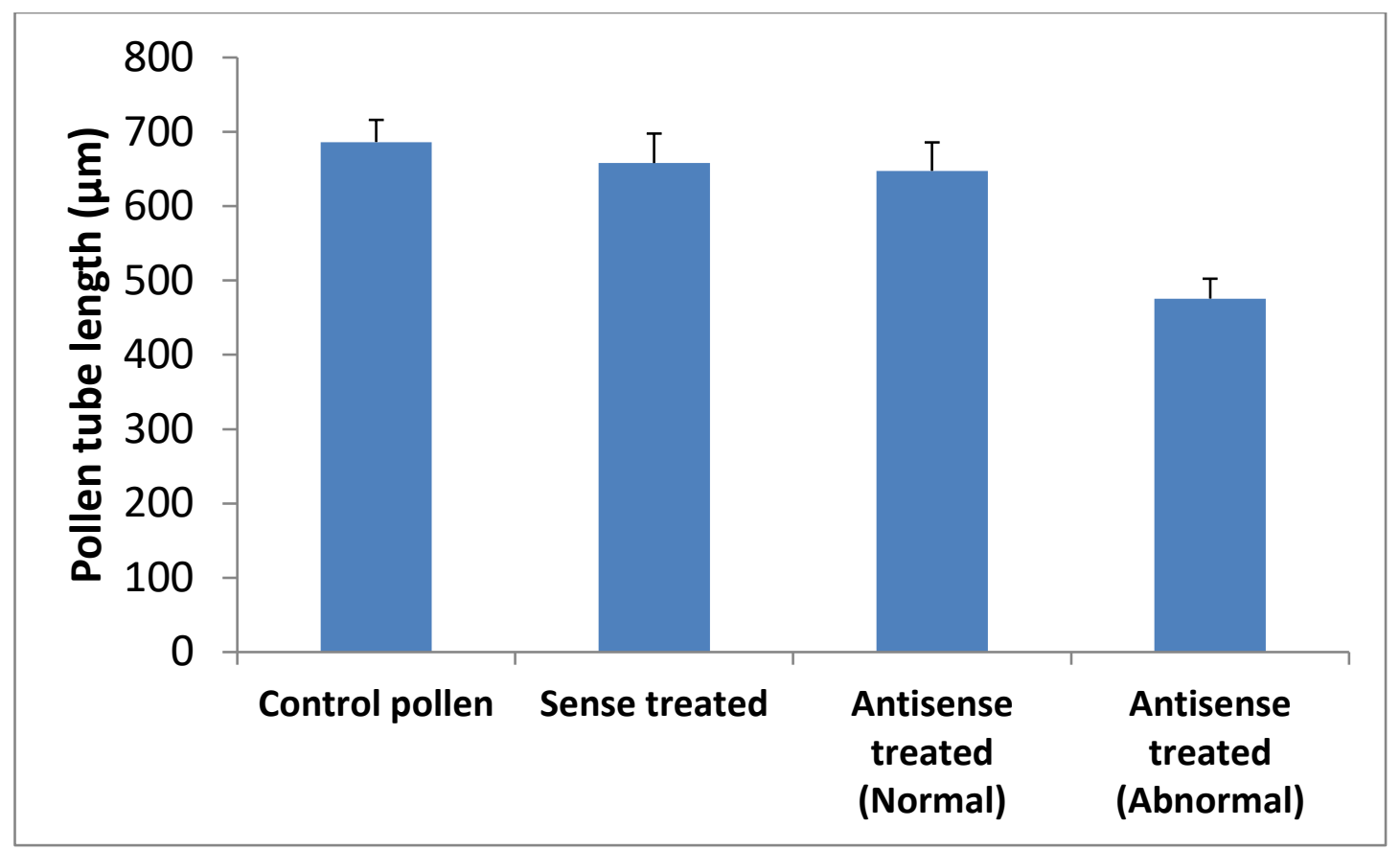

Fig. 17. Pollen tube abnormalities are associated with decreased pollen tube length. The length of 60-60 pollen tubes were measured per treatment. In the case of antisense oligotreated pollen tubes the averages of normal and abnormal tubes were calculated and are shown separately. The average and standard deviation is shown. 


\section{CHAPTER 6: DISCUSSION}

\subsection{The effect of exogenously applied polyamines (PAs) on pollen germination and the apical growth of pollen tube}

The significance of polyamine homeostasis in pollen development and pollen tube growth is well documented in several species (Aloisi et al. 2016). The polycationic properties of PAs showed an important role in cell growth and development (Aloisi et al. 2016; Pegg and Casero 2011), and in vast range of biotic and abiotic stress responses (Gémes et al. 2016, 2017; Moschou et al. 2008; Wu et al. 2010). Exogenous application of PAs to pollen cultures disturbs this homeostasis and affects pollen maturation, germination and tube elongation depending on the dose and structure of PAs (Aloisi et al. 2015).

Exogenous PAs may interact with pollen germination interfering with several interdependent processes such as $\mathrm{ROS}$ production, $\mathrm{Ca}^{2+}$ signalling, actin organization, and cell wall remodelling (Aloisi et al 2017; Aloisi et al. 2016; Wu et al. 2010). In addition to $\mathrm{Ca}^{2+}, \mathrm{pH}$ also plays a role in pollen tube growth (Feijó et al. 1999; Fricker, White, and Gerhard 1997). F-actin remodelling, the origin of polarity, and maintaining acidic condition which is necessary to support the pollen tube elongation (Hepler et al. 2006; Holdaway et al 2003).

Exogenous polyamines are also known to induce the rapid biosynthesis of nitric oxide (NO) in Arabidopsis thaliana seedlings (Tun et al. 2006). NO was shown to regulate pollen tube orientation and growth (Prado et al. 2004). NO, and ROS actions strongly inter relate during stress responses as well as developmental regulation (Hancock and Neill 2019). The mechanism of plant pollen tube growth was also tightly linked to the proper temporal and spatial adjustment of NO and ROS levels (Sírováa et al. 2011). However, the possible link between ROS and NO in the regulation of pollen germination and pollen tube growth is poorly characterized. We found that the natural polyamines Put, Spm, and Spd differentially affects the relative NO/ROS ratio in tobacco pollen grains/tubes and this correlates with their effects on pollen germination and pollen tube elongation, respectively.

Exogenous PAs strongly affect pollen germination, maturation, and pollen tube elongation (Aloisi et al. 2016; Singh and Tandon 2012). Analysing the effect of the three polyamines on 
the germination rate in tobacco pollens, we observed that Put and Spd increased, Spm decreased pollen germination rate compared to the control. To examine whether polyamines affected germination rate through to the regulation of ROS and/or NO accumulation, the levels of these compounds were investigated in the treated pollen grains. While none of the three polyamine treatments caused any changes in the NO level, all of them affected ROS accumulation. Put and Spd decreased, but Spm increased ROS levels in pollen grains compared to the controls.

In the case of PAs deficiency (Chattopadhyay et al. 2006), cells accumulated ROS in the spe 2 mutant of Saccharomyces cerevisiae (Chattopadhyay et al. 2006), and the overexpression of $\mathrm{Cu}-\mathrm{Zn}$ SOD (superoxide dismutase) reduced the accumulation of ROS and protected polyamine-deficient cells from toxic effects of oxygen (Balasundaram et al. 1993; Chattopadhyay et al. 2006). Co-application of Spm with the ROS scavenger DMTU reduced ROS production which caused an increase in pollen germination rate compared to the Spm treated pollens. Next, the effect of the exogenously applied polyamines on pollen tube length was investigated. Among the three polyamines, Put decreased, but Spd enhanced pollen tube length compared to the control, while Spm had no effect.

Considering the level of ROS and NO levels in growing pollen tubes, the NO level could be well correlated with the measured pollen tube length: Put decreased, but Spd increased NO production while Spm did not have a significant effect on it. It was also observed that Put and Spm did not alter the ROS level of pollen tubes but the Spd treatment reduced it significantly in comparison to the untreated controls.

To investigate that the observed changes in NO and/or ROS levels only correlates with or are the cause of the observed pollen tube growth phenotypes, the NO and ROS levels were manipulated in the polyamine treated pollen tubes. The NO-donor SNAP resulted in NO accumulation and complemented the negative effect of Put on pollen tube length without altering the ROS level.

In Spd-treated pollen tubes, the NO scavenger cPTIO reduced the accumulation of NO and thus inhibited the positive effect of the treatment on pollen tube growth without affecting 
the ROS level. Interestingly, ROS accumulation due to exogenous $\mathrm{H}_{2} \mathrm{O}_{2}$ application reduced the endogenous NO level and concomitantly pollen tube length in Spd-treated pollen tubes in comparison to controls. These observations indicate that a high NO/low ROS ratio promotes while the opposite inhibits tobacco pollen tube growth and polyamines differentially affect this ratio primarily via decreasing (Put) or increasing ( $\mathrm{Spd}$ ) the NO level. These results are somewhat in contrast with previous studies in which the negative regulatory role of $\mathrm{NO}(\mathrm{He}$ et al. 2007; Jimenez-Quesada et al. 2017; Pasqualini et al. 2015; Prado et al. 2004; Pradoa et al. 2008) and the positive role of ROS (Hidetaka et al. 2014) in pollen tube growth have been reported. This contradiction might be explained by differences in the endogenous

NO and/or ROS levels that could be achieved in the various experimental systems using various treatments affecting the ratio of these interrelated regulators. NO and ROS are strongly interconnected and their dose-dependent cellular effects are also inter-reliant (Hancock and Neill 2019). Exogenous PAs may co-ordinately regulate both endogenous NO and ROS levels since they are known to induce ROS (Moschou et al 2014) as well as NO (Tun et al. 2006) production or to serve as ROS scavengers (Aloisi et al. 2015). In our experiments, the relatively low exogenous PA concentrations $(10 \mu \mathrm{M})$ might only fine tune the NO/ROS ratio in comparison to other more harsh treatments (e.g. direct exogenous application of NO or ROS).

\subsection{The functional analysis of the RLCK Class VI_A family in tobacco pollen tubes}

The At RLCK VI kinase family has 14 members belonging to two groups in Arabidopsis (Jurca et al. 2008). The first group RLCK VI_A (characterized by N-terminal serine-rich region) contains ROP-interacting and the second group RLCK VI_B (characterized by N-terminal UspA domain, Kerk et al. 2003) ROP-non-interacting kinases (Jurca et al. 2008). Members of the RLCK VI_A group are the only currently known plant kinases the activity of which is dependent on their binding to active (GTP-bound) ROP G-proteins (Dorjgotov et al. 2009; Lajkó et al. 2018). Besides the ROP-dependent regulation of their activity, there is information about the expression of the members of this family in Arabidopsis thaliana. Jurca et al. (2008) reported that all At RLCK VI_A genes are only weakly expressed in dividing cultured cells 
while they exhibit various expression patterns in the plant organs. In the rosette and/or cauline leaves RLCK VI_A2, and A4, in the root RLCK VI_A4, in the inflorescence stem RLCK VI_A5, in flower buds and open flowers RLCK VI_A6 and A7, and in the open flower RLCK VI_A3 gene showed the highest expression level. Moreover, several of these genes (At RLCK A3, A6, and A7) of these genes exhibited strong expression in the pollen.

Considering their ROP-dependent in vitro activity, one can suppose that the At RLCK VI_A kinases have important roles in ROP G-protein regulated processes as ROP effectors. ROP GTPases are well known to regulate cell polarity and one of the best characterized processes in this respect is the polar growth (tip growth) of pollen tubes (Gu et al. 2005; Guan et al. 2013; Lee et al. 2008; Li et al. 1999). Based on the strong expression of some of the At RLCK VI_A kinases in pollen, we decided to test whether they are also involved in the regulation of pollen tube growth and/or polarity.

In plant functional analysis of genes is frequently based on loss-of-function and/or gain-of function experiments. Loss of gene function is generally achieved by mutagenesis, gene silencing, or, recently, by genome engineering while the effects of gain of gene function can be studied in transgenic plants ectopically overexpressing the given gene. Considering the lengthy procedure to obtain mutant or transgenic plants and the possibility that interfering with pollen tube growth can seriously affect their fertility, we decided to use a transient gene silencing approach based on antisense oligonucleotides (AS-ODN).

There are several reports about the use of AS-ODNs for similar studies. Mizuta and Higashiyama (2014) reported that using AS-ODNs against the genes coding for the ANX1 and ANX2 receptor kinases, which implicated in cell wall maintenance, caused short, knotted and ruptured morphology of Arabidopsis thaliana pollen tubes (Mizuta and Higashiyama 2014). They also treated pollen tubes with AS-ODNs against ROP1 and CalS5 and that resulted in waving or short PTs with a few callose plugs (Mizuta and Higashiyama 2014), respectively Liao et al. (2013) characterized the role of the NtGNL1, a guanine exchange factor (GEF) for the Arf family of G- proteins that play crucial roles in vesicle trafficking. Antisense-mediated silencing of the gene MdCBL5 gene encoding a calcineurin B subunit protein disrupted the 
calcium ion concentration gradient in the pollen tube apex and inhibited pollen tube growth in apple (Gu et al. 2015).

The AS-ODN technology seems to be a very good technique for high-throughput screening of genes and proteins with yet unknown functions in pollen tubes. It has the advantage that it can be used for species with only partially covered genome sequence because it requires less than hundreds of base pairs for AS-ODN designing. This also means that specific regions discriminating among the members of a gene family can be differentially targeted. Drawback of AS-ODN technology is that only partial reductions of the target gene expression can be achieved and only temporarily. The reduction of target gene expression varies between 40 to $80 \%$ depending on the AS-ODN designing (Bezvoda et al. 2014; Sun et al. 2005). Determining silencing efficiency in pollen tubes is very difficult due to the limited number of experimental materials, the unknown efficiency of transfection efficiency etc. Attempts were made using fluorescently labelled AS-ODNs but problems were encountered considering the washing out of oligonucleotides that were not taken up by the pollen tubes and caused considerable background fluorescence without compromising pollen tube loss and viability (data not shown). Further optimisations of the procedure are required in this respect.

Although there are reports about the use of the AS-ODN technology for Arabidopsis pollen tubes (Mizuta and Higashiyama 2014), we had difficulties to reproducibly germinate and grow Arabidopsis pollens. Nicotiana tabacum pollen, however, can easily be collected and cultured and were routinely used in our laboratory for gain-of-function studies (Fodor-Dunai et al. 2011; Lajkó et al. 2018). Therefore, members of the RLCK VI_A family of Nicotiana tabacum were identified based on their homology to the Arabidopsis sequences. Four of the seven tobaccos RLCK VI_A kinases (A3, A4, A6, A7) expressed in the pollen were selected for AS-ODN design that followed standard procedures.

The silencing of the selected kinase genes was done one by one. The As-ODN treatments resulted in all cases (Nt RLCK VI_A3, 4, 6 and 7) in the formation of branches, knot, widened or bubble-like tip structure of the pollen tubes. The types of abnormalities were only slightly varying from one kinase to others, although care was taken to design specific antisense 
oligonucleotides against the given kinase cDNA sequences. One can suppose that all investigate kinase take similar and partly overlapping roles in the pollen tube that results only in around 10-15\% of abnormalities if only one of them is silenced. Parallel silencing of several of these kinases would be required in this case to cause a stronger phenotype.

In the treatment of AS-ODN in pollen caused branch formation more frequently rather than knots in the middle or widening/bubble formation at the tip. Waving and limited growth was reported for AS-ODN treatments against At ROP1 in Arabidopsis pollen, tubes but branching not (Mizuta and Higashiyama 2014). Widening or bubble-like tip formation is characteristic for pollen tubes ectopically expressing wild-type or constitutively active ROP1 (Fodor-Dunai et al. 2011; Lajkó et al. 2018) due to the loss of polarity. Branching of pollen tubes indicate that more than one polarity sites were established during pollen tube growth. Knots might also represent sites where polarity was temporarily lost. Therefore, the phenotypes observed in pollen tubes treated by RLCK VI_A specific AS-ODNs support the view that these kinases might be involved in ROP GTPase-mediated signalling controlling polarity establishment and tip growth. This is further supported by the specific interaction of the kinases with active ROP GTPases in pollen tubes as was earlier demonstrated by Lajkó et al. (2018). 


\section{CHAPTER 7: CONCLUSIONS}

Pollen tube growth is a complex and well-coordinated process governed by various cellular and molecular pathways. In this study, 1) the effect of different exogenous polyamines on tobacco pollen germination and growth was studied through their influence on ROS and NO production; 2) the role of ROP-activated Receptor Like Cytosolic Kinases (RLCKs) in pollen tube growth was investigated using antisense oligonucleotide-mediated gene silencing.

Polyamines applied at a low concentration $(10 \mu \mathrm{M})$ affected pollen germination and elongation differentially. Their negative influence on pollen germination rate was dependent on their effect on ROS, but not NO level. However, during pollen tube growth they had a more complex effect on the NO/ROS ratio. The relatively high NO/low ROS ratio promoted, while the opposite inhibited pollen tube elongation. Taken together, our results further support the involvement of PAs in the regulation of pollen germination and elongation affecting primarily ROS or NO levels, respectively, but the outcome might be determined in both cases by the endogenous NO/ROS ratio. Although, these data contribute to our understanding of how PAs exert their effects on pollen germination and tube elongation, many pieces of the puzzle are still missing to complete the picture of the mechanisms controlling these processes. Further investigations on the physiological function of PAs and their molecular partners are still needed. Especially as it seems that there is a wide variation in this respect among the various species and experimental systems.

A group of Receptor Like Cytosolic Kinases (RLCK VI_A) has been previously shown to be in vitro activated by ROP GTPases but their functions in plant were not investigated yet. Based on their pollen specific expression, four Nicotiana tabacum RLCK VI_A kinases were selected to reveal their potential role in polar pollen tube growth that is a well-known ROP-regulated process. Partial silencing of RLCK VI_A kinase members was attempted using specifically designed antisense oligonucleotides taken up into the growing pollen tubes. The observed phenotypes of the treated pollen tubes support the view that these kinases are indeed involved in the ROP GTPase-mediated polarity establishment and tip growth processes. However, further investigations need to be performed to verify this finding including the determination 
of the silencing efficiency and the specificity of the oligonucleotides in association with the observed phenotypes. 


\section{CHAPTER 8: ÖSSZEFOGLALÁS}

A pollencső növekedése egy komplex, celluláris és molekuláris szinten jól koordinált folyamat. Ezzel kapcsolatban munkánk során azt vizsgáltuk, hogy 1) a különféle poliaminoknak a dohány pollenek csírázására és a pollencső növekedésére gyakorolt hatása összefügg-e a reaktív oxigén fajták (ROS) és a nitrogén monoxid (NO) szintjében bekövetkező változásokkal, illetve, hogy 2) antiszenz oligonukleotiddal csendesítve egy speciális kináz család tagjainak génjeit milyen változások következnek be a dohány pollencső poláris növekedésében.

Alacsony $(10 \mu \mathrm{M})$ koncentrációban alkalmazva a különböző poliaminok eltérő módon hatottak a pollencsírázásra és a pollencső növekedésére. A pollencsírázásra való negatív hatásuk összefüggést mutatott a pollen ROS szintjének növekedésével, míg a NO szintek esetében ilyen összefüggés nem volt megállapítható. A pollencső növekedése alatt a hatás komplexebbnek bizonyult, és a relatív NO/ROS arány változása volt megfigyelhető. A viszonylag magas NO és alacsonyabb ROS szint serkentette, míg az ellenkező irányú változás gátolta a pollencsövek megnyúlását. Eredményeink alapján a poliaminok mind a pollen csírázását, mind a pollencső növekedését specifikusan befolyásolják, és hatásuk a ROS és/vagy NO szintek (arányok) specifikus megváltoztatásával mutat összefüggést. Bár ezek az adatok hozzájárulnak a poliaminok pollencsírázásra és a pollencső-növekedésre gyakorolt hatásának jobb megértéséhez, még számos kérdés megválaszolása szükséges a folyamatok teljes feltérképezéséhez. Többek között szükség van a poliaminok fiziológiai hatásmechanizmusának és molekuláris partnereinek mélyebb megismerésére. Annál is inkább, mert a különböző fajok és kísérleti rendszerek esetében rendelkezésre álló kutatási eredményekben között nagyok az eltérések.

Egy növényspecifikus kináz csoport (Receptor Like Cytoplasmic Kinases Class VI group A; RLCK VI_A) tagjairól ismertté vált, hogy in vitro aktivitásukat kis molekulasúlyú GTP-kötő fehérjék (ROP GTPázok) szabályozzák, de a növényekben betöltött funkcióikról még alig állnak rendelkezésre adatok. Mivel számos tagja a csoportnak pollenben magas szinten termelődik, elhatároztuk, hogy megvizsgáljuk négy dohány (Nicotiana tabacum) kináz szerepét ebben a közismerten ROP GTPázok által szabályozott folyamatban. A kinázok 
génjeinek részleges csendesítését specifikusan tervezett antiszenz oligonukleotidokkal kíséreltük meg. Az oligonukleotidokkal kezelt pollencsövek növekedésében megfigyelt változások alapján feltételezhetjük, hogy a kinázok részt vesznek a ROP GTPázok által kontrollált poláris növekedés fenntartásában. Azonban további vizsgálatok kell elvégezni ahhoz, hogy a megfigyelt változások konkrét molekuláris, illetve celluláris hátterére fényt deríthessünk. Ehhez elsőként igazolni kell az oligonukleotidok által kiváltott géncsendesítés specifikusságát és hatékonyságát. 


\section{REFERENCES}

Abdelgadir, H. A., S. D. Johnson, and J. Van Staden. 2012. "Pollen Viability, Pollen Germination and Pollen Tube Growth in the Biofuel Seed Crop Jatropha Curcas ( Euphorbiaceae )." South African Journal of Botany 79:132-39.

Allan, A. C. 1997. "Two Distinct Sources of Elicited Reactive Oxygen Species in Tobacco Epidermal Cells.” The Plant Cell Online 9(9):1559-72.

Aloisi, Iris. 2017. "Factors Involved in Pollen Germination Playing a Critical Role Also in Allergic Sensitization.” Università di Bologna.

Aloisi, Iris, Giampiero Cai, Donatella Serafini-fracassini, and Stefano Del Duca. 2016. "Polyamines in Pollen : From Microsporogenesis to Fertilization." Frontiers in Plant Science 7(February):1-7.

Aloisi, Iris, Giampiero Cai, Vincenzo Tumiatti, Anna Minarini, and Stefano Del Duca. 2015. "Natural Polyamines and Synthetic Analogs Modify the Growth and the Morphology of Pyrus Communis Pollen Tubes Affecting ROS Levels and Causing Cell Death.” Plant Science 239:92-105.

Alvarez, E., Roger I. Pennell, Per-johan Meijer, Atsushi Ishikawa, Richard A. Dixon, and Chris Lamb. 1998. "Reactive Oxygen Intermediates Mediate a Systemic Signal Network in the Establishment of Plant Immunity." Cell 92:773-84.

Anderhag, P., P. K. Hepler, and M. D. Lazzaro. 2000. "Microtubules and Microfilaments Are Both Responsible for Pollen Tube Elongation in the Conifer Picea Abies ( Norway Spruce ).” Protoplasma 214:141-57.

Asada, Kozi. 1999. “THE WATER-WATER CYCLE IN CHLOROPLASTS: Scavenging of Active Oxygens and Dissipation of Excess Photons." Annual Review of Plant Physiology and Plant Molecular Biology 50(1):601-39.

Astrom, Helena, Outi Sorri, and Marjatta Raudaskoski. 1995. "Role of Microtubules in the Movement of the Vegetative Nucleus and Generative Cell in Tobacco Pollen Tubes.” Sex Plant Reprod (1995) 8:61-69.

Ãy, Tetsuya Higashiyama, Haruko Kuroiwa, and Tsuneyoshi Kuroiwa. 2003. "Pollen-Tube Guidance : Beacons from the Female Gametophyte.” Current Opinion in Plant Biology $6: 36-41$. 
Balasundaram, David, Celia White Tabor, and Tabor Herbert. 1993. "Oxygen Toxicity in a Polyamine-Depleted Spe2A Mutant of Saccharomyces Cerevisiae." Proc. Natl. Acad. Sci. 90(May):4693-97.

Berken, Antje and Alfred Wittinghofer. 2008. "Structure and Function of Rho-Type Molecular Switches in Plants." Plant Physiology and Biochemistry 46:380-93.

Bezvoda, Radek, Roman Pleskot, Viktor Žárský, and Martin Potocký. 2014. “Antisense Oligodeoxynucleotide-Mediated Gene Knockdown in Pollen Tubes.” Pp. 231-36 in Plant Cell Morphogenesis: Methods and Protocols, Methods in Molecular Biology. Vol. 1080, edited by Viktor Žárský and Fatima Cvrc ková. Springer Science.

Boisson-Derniera, Aurélien, Christina Maria Francka, Dmytro S. Lituiev, and Ueli Grossniklaus."Receptor-like Cytoplasmic Kinase MARIS Functions Downstream of $\mathrm{Cr}$ RLK1L-Dependent Signaling during Tip Growth.” PNAS, vol 112,no. 39,pp1221112216, 2015.

Bosch, M. 2005. "Pectin Methylesterases and Pectin Dynamics in Pollen Tubes." The Plant Cell 17(December):3219-26.

Brewbaker, James L. and Beyoung H. Kwack. 1963. "The Essential Role of Calcium Ion in Pollen Germination and Pollen Tube Growth." American Journal of Botany 50(9):85965.

Breygina, M. A., D. V Abramochkin, N. M. Maksimov, and I. P. Yermakov. 2016.

"Hydrogen Peroxide Affects Ion Channels in Lily Pollen Grain Protoplasts." Plant Biology 18(April):761-767.

Breygina, M. A., N. P. Matveyeva, D. S. Andreyuk, and I. P. Yermakov. 2012.

"Transmembrane Transport of $\mathrm{K}+$ and $\mathrm{Cl}-$ during Pollen Grain Activation in Vivo and in Vitro." Russian Journal of Developmental Biology 43(2):85-93.

Cameron, Christine and Anja Geitmann. 2018. "Cell Mechanics of Pollen Tube Growth." Current Opinion in Genetics and Development 51:11-17.

Cárdenas, Luis, Alenka Lovy-Wheeler, Joseph G. Kunkel, and Peter K. Hepler. 2008.

"Pollen Tube Growth Oscillations and Intracellular Calcium Levels Are Reversibly Modulated By." Plant Physiology 146(April):1611-21.

Caser, Matteo. 2018. "Pollen Grains and Tubes." In Encyclopedia of Rose Science.

Chai, Sen, Furong Ge, Sha Li, and Yan Zhang. 2015. "The Journey to Glory : Receptor-like 
Kinases in Pollen Tube Growth." Science Bulletin.

Chan, Jasmine H. P., Shuhui Lim, and W. S. Fred Wong. 2006a. "Antisense

Oligonucleotides : From Design to Therapeutic Application." Clinical and Experimental Pharmacology and Physiology 33(February):533-40.

Chan, Jasmine H. P., Shuhui Lim, and W. S. Fred Wong. 2006b. "Antisense Oligonucleotides: From Design To Therapeutic Application." Clinical and Experimental Pharmacology and Physiology 33(February):533-40.

Chanda, S. and R. Dave. 2009. "In Vitro Models for Antioxidant Activity Evaluation and Some Medicinal Plants Possessing Antioxidant Properties : An Overview." African Journal of Microbiology Research 3(13):981-96.

Chattopadhyay, Manas K., Celia White Tabor, and HerbertTabor. 2006. "Polyamine Deficiency Leads to Accumulation of Reactive Oxygen Species in a Spe2? Mutant of Saccharomyces Cerevisiae.” Wiley InterScience 23:751-61.

Chebli, Youssef and Anja Geitmann. 2014. "Mechanical Principles Governing Pollen Tube Growth.” Pp. 232-45 in Functional Plant Science and Biotechnology.

Chen, Y. Q. Li .. F., H. F. Linskens, and M. Cresti. 1994. "Distribution of Unesterified and Esterified Pectins in Cell Walls of Pollen Tubes of Flowering Plants." Sex Plant Reprod $7: 145-52$.

Cheung, Alice Y., Qiao-hong Duan, Silvia Santos, Barend H. J. De Graaf, and Veronica S. Di. 2008. "Dynamic Pollen Tube Cytoskeleton : Live Cell Studies Using Actin-Binding and Microtubule- Binding Reporter Proteins." Molecular Plant 1-7.

Cheung, Alice Y., Hong Wang, and Hen-ming Wu. 1995. "A Floral Transmitting TissueSpecific Glycoprotein Attracts Pollen Tubes and Stimulates Their Growth.” Cell 82:383-93.

Clark, Steven E., Robert W. Williams, and Elliot M. Meyerowitz. 1997. "The CLAVATA1 Gene Encodes a Putative Receptor Kinase That Controls Shoot and Floral Meristem Size in Arabidopsis." Cell 89:575-85.

Coelho, Susana M., Alison R. Taylor, Keith P. Ryan, Isabel Sousa-pinto, Murray T. Brown, and Colin Brownlee. 2002. "Spatiotemporal Patterning of Reactive Oxygen Production and Ca 2+ Wave Propagation in Fucus Rhizoid Cells." The Plant Cell 14(October):2369-81. 
Cona, Alessandra, Giuseppina Rea, Riccardo Angelini, Rodolfo Federico, and Paraskevi Tavladoraki. 2006. "Functions of Amine Oxidases in Plant Development and Defence." Trends in Plant Science 11(2):80-88.

Corpas, Francisco J., Juan B. Barroso, and Luis A. Del Río. 2001. "Peroxisomes as a Source of Reactive Oxygen Species and Nitric Oxide Signal Molecules in Plant Cells." Trends in Plant Science 6(4):145-50.

Dagle, John M. and Daniel L. Weeks. 2001. “Oligonucleotide-Based Strategies to Reduce Gene Expression.” Differentiation 69:75-82.

Demidchik, Vadim, Sergey N. Shabala, and Julia M. Davies. 2007. "Spatial Variation in H 2 O 2 Response of Arabidopsis Thaliana Root Epidermal Ca 2 p Flux and Plasma Membrane Ca 2 p Channels." The Plant Journal 49:377-86.

Derksen, J. A. N., Twan Rutten, T. O. N. V. A. N. Amstel, Anna D. E. Win, Fiona Doris, and Martin Steer. 1995. "Regulation of Pollen Tube Growth.” Acta Bot. Neerl. 44(2), 44(June):93-119.

Derksen, J., T. Rutten, I. K. Lichtscheidl, A. H. N. De Win, E. S. Pierson, and G. Rongen. 1995. "Quantitative Analysis of the Distribution of Organelles in Tobacco Pollen Tubes : Implications for Exocytosis and Endocytosis.” Protoplasma 188:267-76. Dhonukshe, Pankaj, Fernando Aniento, Inhwan Hwang, David G. Robinson, and Jozef Mravec. 2007. "Report Clathrin-Mediated Constitutive Endocytosis of PIN Auxin Efflux Carriers in Arabidopsis." Current Biology 17:520-27.

Dinç, Emine, Szilvia Z. Tóth, Gert Schansker, Ferhan Ayaydin, László Kovács, Dénes Dudits, Győző Garab, and Sándor Bottka. 2011. "Synthetic Antisense Oligodeoxynucleotides to Transiently Suppress Different Nucleus- and ChloroplastEncoded." Plant Physiology 157(December):1628-41.

Ding, Ye, Chi Yu Chan, and Charles E. Lawrence. 2004. "Sfold Web Server for Statistical Folding and Rational Design of Nucleic Acids." Nucleic Acids Research 32:135-41. Dorjgotov, Dulguun, Manuela E. Jurca, Csilla Fodor-Dunai, Attila Szucs, Krisztina Ötvös, Éva Klement, Judit Bíró, and Attila Fehér. 2009. "Plant Rho-Type ( Rop ) GTPaseDependent Activation of Receptor-like Cytoplasmic Kinases in Vitro.” FEBS Letters 583:1175-82.

Dresselhaus, Thomas and Noni Franklin-tong. 2013. "Male - Female Crosstalk during Pollen 
Germination, Tube Growth and Guidance, and Double Fertilization." Molecular Plant 6(4):1018-36.

Dua, Changqing, Xiushan Lia, Jia Chena, Weijun Chena, Bin Lia, Chiyu Lia, Long Wanga, Jianglin Lia, Xiaoying Zhaoa, Jianzhong Lina, Xuanming Liua, Sheng Luanb, and Feng Yua. 2016. "Receptor Kinase Complex Transmits RALF Peptide Signal to Inhibit Root Growth in Arabidopsis.” PNAS E8326-34.

Eckstein, Fritz. 2000. "Phosphorothioate Oligodeoxynucleotides : What Is Their Origin and What Is Unique About Them?” Antisense \& Nucleic acid Drug Development 10:11721.

Estruch, Juan J., S. U. E. Kadwell, Ellis Merlin, and Lyle Crossland. 1994. “Cloning and Characterization of a Maize Pollen-Specific Calcium-Dependent CalmodulinIndependent Protein Kinase.” Proc. Natl. Acad. 91(September):8837-41.

Fayant, Pierre, Orlando Girlanda, Youssef Chebli, Carl-Eric Aubin, Isabelle Villemure, and Anja Geitmann. 2010. "Finite Element Model of Polar Growth in Pollen Tubes.” The Plant Cell 22(August):2579-93.

Fehér, Attila and Dézi Bianka Lajkó. 2015. "Signals Fly When Kinases Meet Rho-of-Plants ( ROP ) Small G-Proteins.” Plant Science 237:93-107.

Feigl, Gábor, Devanand Kumar, Nóra Lehotai, Nóra Tugyi, Árpád Molnár, Attila Ördög, Ágnes Szepesi, Katalin Gémes, Gábor Laskay, László Erdei, and Zsuzsanna Kolbert. 2013. "Ecotoxicology and Environmental Safety Physiological and Morphological Responses of the Root System of Indian Mustard ( Brassica Juncea L . Czern .) and Rapeseed ( Brassica Napus L .) to Copper Stress.” Ecotoxicology and Environmental Safety 94:179-89.

Feiguelman, Gil, Ying Fu, and Shaul Yalovsky. 2018. "Update on ROP Function and Signaling ROP GTPases Structure-Function And.” Plant Physiology 176(January):5779.

Feijó, J. A., J. Sainhas, G. R. Hackett, J. G. Kunkel, and P. K. Hepler. 1999. “Growing Pollen Tubes Possess a Constitutive Alkaline Band in the Clear Zone and a Growth-Dependent Acidic Tip.” Journal of Cell Biology 144(3):483-96.

Fodor-Dunai, Fricke I, Potocký M, Dorjgotov D, Domoki M, Jurca ME, Otvös K, Zárský V, Berken A, and Fehér A. 2011. "The Phosphomimetic Mutation of an Evolutionarily 
Conserved Serine Residue Affects the Signaling Properties of Rho of Plants ( ROPs )." The Plant Journal 66:669-79.

Freier, Susan M., Olga Matveeva, Alexander Tsodikov, Michael C. Giddings, and Jacqueline R. Wyatt. 2004. "Patent Application Publication: US 2004/0115716A1." Patent Application Publication 1(19).

Fricker, Mark D., Nick White, and Obermeyer Gerhard. 1997. "PH Gradients Are Not Associated with Tip Growth in Pollen Tubes of Lilium Longiflorum.” Journal of Cell Science 110 ( Pt 1(May 2014):1729-40.

Fricker, Mark D., Nick White, and Gerhard Obermeyer. 1997. "PH Gradients Are Not Associated with Tip Growth in Pollen Tubes of Lilium Longiflorum PH Gradients Are Not Associated with Tip Growth in Pollen Tubes of Lilium Longiflorum." Journal of Cell Science 110(August):1729-40.

Fry, Stephen C. 1986. "Cross-Linking Of Matrix Polymers In The Growing Cell Walls Of Angiosperms." Ann. Rev. Plant Physiol 37:165-86.

Galston, Arthur W. and Ravindar K. Sawhney. 1990. "Polyamines in Plant Physiology1." Plant Physiol 94:406-10.

Ge, Zengxiang, Tabata Bergonci, Yuling Zhao, Yanjiao Zou, Shuo Du, Ming-Che Liu, Xingju Luo, Hao Ruan, Liliana E. García-Valencia, Sheng Zhong, Saiying Hou, Qingpei Huang, Luhua Lai, Daniel S. Moura, Hongya Gu, Juan Dong, Hen-Ming Wu, Thomas Dresselhaus, Junyu Xiao, Alice Y. Cheung, and Li-Jia Qu. 2017. “Arabidopsis Pollen Tube Integrity and Sperm Release Are Regulated by RALF- Mediated Signaling." Science 385:1596-1600.

Gémes, Katalin, Yu Jung Kim, Ky Young Park, Panagiotis N. Moschou, Efthimios Andronis, Chryssanthi Valassaki, Andreas Roussis, and Kalliopi A. Roubelakis-angelakis. 2016. "An NADPH-Oxidase / Polyamine Oxidase Feedback Loop Controls Oxidative Burst Under Salinity 1." Plant Physiology 172(November):1418-31.

Gémes, Katalin, Nullfigeneia Mellidou, Katerina Karamanoli, Despoina Beris, Ky Young Park, Theodora Matsi, Kosmas Haralampidis, Helen-Isis Constantinidou, and Kalliopi A. Roubelakis-Angelakis. 2017. "Deregulation of Apoplastic POLYAMINE OXIDASE Affects Development and Salt Response of Tobacco Plants." Journal of Plant Physiology. 
Gémes, Katalin, Peter Poor, Edit Horvath, Zsuzsanna Kolbert, Dora Szopko, Agnes' Szepesi, and Irma Tari. 2011. "Cross-Talk between Salicylic Acid and NaCl-Generated Reactive Oxygen Species and Nitric Oxide in Tomato during Acclimation to High Salinity." Physiologia Plantarum 142:179-92.

Gewirtz, Alan M., Deborah L. Sokol, and Mariusz Z. Ratajczak. 1998. "Nucleic Acid Therapeutics : State of the Art and Future Prospects.” Blood 92(3):712-36.

De Graaf, Barend H. J., Alice Y. Cheung, Tatyana Andreyeva, Kathryn Levasseur, Marcia Kieliszewski, and Hen-ming Wu. 2005. "Rab11 GTPase-Regulated Membrane Trafficking Is Crucial for Tip-Focused Pollen Tube Growth in Tobacco." The Plant Cell 17(September):2564-79.

Grant, John J. and Gary J. Loake. 2000. "Role of Reactive Oxygen Intermediates and Cognate Redox Signaling in Disease Resistance.” Plant Molecular Biology 124(September):21-29.

Gu, Ying, Ying Fu, Peter Dowd, Shundai Li, Vanessa Vernoud, Simon Gilroy, Ying Gu, Ying Fu, Peter Dowd, Shundai Li, Vanessa Vernoud, Simon Gilroy, and Zhenbiao Yang. 2005. “A Rho Family GTPase Controls Actin Dynamics and Tip Growth via Two Counteracting Downstream Pathways in Pollen Tubes." The Journal of Cell Biology 169(1):127-38.

Gu, Zhaoyu, Dong Meng, Qing Yang, Hui Yuan, Aide Wang, Wei Li, Qiuju Chen, and Yi Zhang. 2015. "A CBL Gene, MdCBL5, Controls the Calcium Signal and Influences Pollen Tube Growth in Apple.” Tree Genetics \& Genomes 11(2).

Guan, Yuefeng, Jingzhe Guo, Hui Li, and Zhenbiao Yang. 2013. "Signaling in Pollen Tube Growth : Crosstalk , Feedback , and Missing Links." Molecular Plant 6(4):1053-64.

Haffani, Yosr Z., Nancy F. Silva, and Daphne R. Goring. 2004. "Receptor Kinase Signalling in Plants." Can. J. Bot. 82:1-15.

Hala, Michal, Rex Cole, Lukas Synek, Edita Drdova, Tamara Pecenkova, Alfred Nordheim, Tobias Lamkemeyer, Johannes Madlung, Frank Hochholdinger, John E. Fowler, and Viktor Zarsky. 2008. “An Exocyst Complex Functions in Plant Cell Growth in Arabidopsis and Tobacco." The Plant Cell 20(May):1330-45.

Hammond-Kosack, Kim E. and Jonathan D. G. Jones. 1996. "Resistance Gene-Dependent Plant Defense Responses." The Plant Cell 8(10):1773. 
Hancock, John T. and Steven J. Neill. 2019. "Nitric Oxide : Its Generation and Interactions with Other Reactive Signaling Compounds.” Plants 8(41):1-14.

He, Jun-min, Xiao-ling Bai, Rui-bin Wang, Bing Cao, and Xiao-ping She. 2007. "The Involvement of Nitric Oxide in Ultraviolet-B-Inhibited Pollen Germination and Tube Growth of Paulownia Tomentosa in Vitro.” Physiologia Plantarum 131:273-82.

He, Lixiong, Yusuke Ban, Hiromichi Inoue, Narumi Matsuda, Jihong Liu, and Takaya Moriguchi. 2008. "Phytochemistry Enhancement of Spermidine Content and Antioxidant Capacity in Transgenic Pear Shoots Overexpressing Apple Spermidine Synthase in Response to Salinity and Hyperosmosis." Phytochemistry 69:2133-41. Helling, Diana, Anja Possart, Stéphanie Cottier, Ulrich Klahre, Benedikt Kost, Diana Helling, Anja Possart, St Cottier, Ulrich Klahre, and Benedikt Kost. 2016. "Pollen Tube Tip Growth Depends on Plasma Membrane Polarization Mediated by Tobacco Plc3 Activity and Endocytic Membrane Recycling Pollen Tube Tip Growth Depends on Plasma Membrane Polarization Mediated by Tobacco PLC3 Activity and Endocytic Membrane Recyc." The Plant Cell 18(12):3519-34.

Hepler, Peter K., Joseph G. Kunkel, Caleb M. Rounds, and Lawrence J. Winship. 2012. “Calcium Entry into Pollen Tubes.” Trends in Plant Science 17(1):32-38.

Hepler, Peter K., Alenka Lovy-Wheeler, Sylvester T. McKenna, and Joseph G. Kunkel. 2006. "Ions and Pollen Tube Growth.” Plant Cell Monographs 3(January):47-69.

Hepler, Peter K., Luis Vidali, and Alice Y. Cheung. 2001. "Polarized Cell Growth in Higher Plants.” Annu. Rev. Cell Dev. Biol. 17:159-87.

Higashiyama, Tetsuya and Hidenori Takeuchi. 2015. "The Mechanism and Key Molecules Involved in Pollen Tube Guidance." Annu. Rev. Plant Biol. (January):1-21.

Holdaway-Clarke, Terena L., José A. Feijó, Grant R. Hackett, Joseph G. Kunkel And, and Peter K. Hepler. 1997. "Pollen Tube Growth and the Intracellular Cytosolic Calcium Gradient Oscillate in Phase While Extracellular Calcium Influx Is Delayed." The Plant Cell Online 9(11):1999-2010.

Holdaway-Clarke, Terena L. and Peter K. Hepler. 2003. "Control of Pollen Tube Growth: Role of Ion Gradients and Fluxes.” New Phytologist 159(3):539-63.

Hwang, Jae-ung, Ying Gu, Yong-jik Lee, and Zhenbiao Yang. 2005. “Oscillatory ROP GTPase Activation Leads the Oscillatory Polarized Growth of Pollen Tubes.” Molecular 
Biology of the Cell 16(November):5385-99.

J. Dat, S. Vandenabeele, E. Vranova', M. Van Montagu, D. Inze' and F. Van Breusegem. 2000. "Dual Action of the Active Oxygen Species during Plant Stress Responses." 57:779-95.

Jimenez-Quesada, María Jose, Rosario Carmona, Elena Lima-Cabello, Jose Angel Traverso, Antonio Jesús Castro, M. Gonzalo Claros, and Juan de Dios Alche. 2017. "Nitric Oxide Generation of Nitric Oxide by Olive ( Olea Europaea L .) Pollen during in Vitro Germination and Assessment of the S-Nitroso- and Nitro- Proteomes by Computational Predictive Methods." Nitric Oxide 1-15.

Jurca, Manuela E., Sandor Bottka, and Attila Fehér. 2008. "Characterization of a Family of Arabidopsis Receptor-like Cytoplasmic Kinases ( RLCK Class VI ).” Plant Cell Reports 27:739-48.

Jurca, Manuela Elena. 2011. "Characterization of ROP GTPase-Activated Arabidopsis Receptor-like Cytoplasmic Kinases ( RLCK Class VI _ A ).” University of Szeged. Kachroo, Aardra, Mikhail E. Nasrallah, and June B. Nasrallah. 2002. "Self-Incompatibility in the Brassicaceae : Receptor - Ligand Signaling and Cell-to-Cell Communication.” The Plant Cell 227-38.

Kadota, Yasuhiro, Ken Shirasu, and Cyril Zipfel. 2015. "Regulation of the NADPH Oxidase RBOHD During Plant Immunity.” 56(May):1472-80.

Kakita, Mitsuru, Kohji Murase, Megumi Iwano, Tomohito Matsumoto, Masao Watanabe, Hiroshi Shiba, Akira Isogai, and Seiji Takayama. 2007. “Two Distinct Forms of M Locus Protein Kinase Localize to the Plasma Membrane and Interact Directly with S Locus Receptor Kinase to Transduce Self-Incompatibility Signaling in Brassica Rapa.” 19(December):3961-73.

Kaya, H., R. Nakajima, M. Iwano, M. M. Kanaoka, S. Kimura, S. Takeda, T. Kawarazaki, E. Senzaki, Y. Hamamura, T. Higashiyama, S. Takayama, M. Abe, and K. Kuchitsu. 2014. "Ca2+-Activated Reactive Oxygen Species Production by Arabidopsis RbohH and RbohJ Is Essential for Proper Pollen Tube Tip Growth.” The Plant Cell 26(3):1069-80. Kaya, Hidetaka, Ryo Nakajima, Megumi Iwano, Masahiro M. Kanaoka, Sachie Kimura, Seiji Takeda, Tomoko Kawarazaki, Eriko Senzaki, Yuki Hamamura, Tetsuya Higashiyama, Seiji Takayama, Mitsutomo Abe, and Kazuyuki Kuchitsu. 2014. "Ca 2 + -Activated 
Reactive Oxygen Species Production by Arabidopsis RbohH and RbohJ Is Essential for Proper Pollen Tube Tip Growth.” The Plant Cell 26(March):1069-80.

Kerk, David, Joshua Bulgrien, Douglas W. Smith, and Michael Gribskov. 2003.

“Arabidopsis Proteins Containing Similarity to the Universal Stress Protein Domain of Bacteria 1.” Plant Physiology 131(March):1209-19.

Kessler, Sharon A. and Ueli Grossniklaus. 2011. "She's the Boss: Signaling in Pollen Tube Reception." Current Opinion in Plant Biology 14(5):622-27.

Knox, J. Paul, Paul J. Linstead, Janet King, Christine Cooper, Keith Roberts, J. Paul Knox, Paul J. Linstead, Janet King, Christine Cooper, and Keith Roberts. 1990. "Pectin Esterification Is Spatially Regulated Both within Cell Walls and between Developing Tissues of Root Apices.” Planta 181(4):512-21.

Kolbert, Zsuzsanna, Andrea Peto, Nora Lehotai, Gabor Feigl, and Laszlo Erdei. 2015. “Copper Sensitivity of Nia1nia2noa1 - 2 Mutant Is Associated with Its Low Nitric Oxide ( NO ) Level.” Plant Growth Regulation.

Kong, Qing, Tongjun Sun, Na Qu, Junling Ma, Meng Li, Yu-ti Cheng, Qian Zhang, Di Wu, and Zhibin Zhang. 2016. "Two Redundant Receptor-Like Cytoplasmic Kinases Function Downstream of Pattern Recognition Receptors to Regulate Activation of SA Biosynthesis.” Plant Physiology 171(June):1344-54.

Kost, Benedikt, Pius Spielhofer, and Nam-hai Chua. 1998. “A GFP-Mouse Talin Fusion Protein Labels Plant Actin Filaments in Vivo and Visualizes the Actin Cytoskeleton in Growing Pollen Tubes.” The Plant Journal 16(3):393-401.

Kurreck, Jens. 2003. “Antisense Technologies Improvement through Novel Chemical Modifications." Eur. J. Biochem 270:1628-44.

Kusano, T., T. Berberich, C. Tateda, and Y. Takahashi. 2008. "Polyamines: Essential Factors for Growth and Survival." Planta 228(3):367-81.

Lajkó, Dézi Bianka, Valkai I, Domoki M, Ménesi D, Ferenc G, Ayaydin F, and Fehér A. 2018. "In Silico Identification and Experimental Validation of Amino Acid Motifs Required for the Rho-of-Plants GTPase-Mediated Activation of Receptor-like Cytoplasmic Kinases." Plant Cell Reports 37(4):627-39.

Lee, Yong Jik, Amy Szumlanski, Erik Nielsen, and Zhenbiao Yan. 2008. "Rho-GTPaseDependent Filamentous Actin Dynamics Coordinate Vesicle Targeting and Exocytosis 
during Tip Growth." The Journal of Cell Biology 181(7):1155-68.

Li, Hai, Yakang Lin, Rachel M. Heath, Michael X. Zhu, and Zhenbiao Yang. 1999. "Control of Pollen Tube Tip Growth by a Rop GTPase-Dependent Pathway That Leads to TipLocalized Calcium Influx.” American Society of Plant Biologists 11(9):1731-42.

Li, Jianming and Joanne Chory. 1997. “A Putative Leucine-Rich Repeat Receptor Kinase Involved in Brassinosteroid Signal Transduction.” Cell 90:929-38.

Liang, Xiangxiu and Jian-min Zhou. 2018. "Receptor-Like Cytoplasmic Kinases : Central Players in Plant Receptor Kinase - Mediated Signaling." Annual Review of Plant Biology 69:267-99.

Liao, Fanglei, Lu Wang, Li-bo Yang, Liyao Zhang, Xiongbo Peng, and Meng-xiang Sun. 2013. "Antisense Oligodeoxynucleotide Inhibition as an Alternative and Convenient Method for Gene Function Analysis in Pollen Tubes.” PLOS ONE 8(3):e59112-e59112.

Lin, Jih-jing and David B. Dickinson. 1984. "Ability of Pollen to Germinate Prior to Anthesis and Effect of Desiccation on Germination." Plant Physiology 74:746-48. Liszkay, Anja, Christian Fufezan, and Achim Trebst. 2008. "Singlet Oxygen Production in Photosystem II and Related Protection Mechanism.” Photosynthesis Research 98(13):551-64.

Liu, Zixu, Ying Wu, Fan Yang, Yiyue Zhang, She Chen, Qi Xie, Xingjun Tian, and Jian-min Zhou. 2013. "BIK1 Interacts with PEPRs to Mediate Ethylene-Induced Immunity." PNAS 110(15):6205-10.

Lord, E. M. and L. C. Sandders. 1992. "Roles for the Extracellular Matrix in Plant Development and Pollination : A Special Case of Cell Movement in Plants." Development 28:16-28.

Lu, Dongping, Shujing Wu, Xiquan Gao, Yulan Zhang, Libo Shan, and Ping He. 2010. “A Receptor-like Cytoplasmic Kinase, BIK1, Associates with a Flagellin Receptor Complex to Initiate Plant Innate Immunity.” PNAS 107(1):496-501.

Lundquist, Erik A. 2006. "Small GTPases.” Pp. 1-18 in WormBook.org, edited by I. Greenwald. WormBook.org.

Malhó, Rui, Nick D. Read, Anthony J. Trewavas, and M. Salome Pais. 1995. “Calcium Channel Activity during Pollen Tube Gmwth and Reorientation.” The Plant Cell 7(August):1173-84. 
Maruyama, Daisuke, Tomoyuki Sugiyama, Toshiya Endo, and Shuh-ichi Nishikawa. 2014. "Multiple BiP Genes of Arabidopsis Thaliana Are Required for Male Gametogenesis and Pollen Competitiveness." Plant and Cell Physiology 55(4):801-10.

Matveeva, O. V, A. D. Tsodikov, M. Giddings, S. M. Freier, J. R. Wyatt, A. N. Spiridonov, S. A. Shabalina, R. F. Gesteland, and J. F. Atkins. 2000. "Identification of Sequence Motifs in Oligonucleotides Whose Presence Is Correlated with Antisense Activity." Nucleic Acids Research 28(15):2862-65.

Miller, Gad, Nobuhiro Suzuki, Sultan Ciftci-Yilmaz, and Ron Mittler. 2010. "Reactive Oxygen Species Homeostasis and Signalling during Drought and Salinity Stresses.” Plant, Cell and Environment 33(4):453-67.

Mittler, Ron. 2002a. “Oxidative Stress, Antioxidants and Periodontal Disease.” TRENDSin Plant Science 7(9).

Mittler, Ron. 2002b. “Oxidative Stress, Antioxidants and Stress Tolerance." Trends in Plant Science 7(9):405-10.

Mizuta, Yoko and Tetsuya Higashiyama. 2014. "Antisense Gene Inhibition by Phosphorothioate Antisense Oligonucleotide in Arabidopsis Pollen Tubes." The Plant Journal 78:516-26.

Molendijk, Arthur J., Benedetto Ruperti, Manoj K. Singh, Alexander Dovzhenko, Franck A. Ditengou, Mattia Milia, Lore Westphal, Sabine Rosahl, Tim-robert Soellick, Joachim Uhrig, Lars Weingarten, Michael Huber, and Klaus Palme. 2008. “A Cysteine-Rich Receptor-like Kinase NCRK and a Pathogen- Induced Protein Kinase RBK1 Are Rop GTPase Interactors.” The Plant Journal 53:909-23.

Moscatelli, A. and M. Cresti. 1992. "Chapter 3 Pollen Germination And Pollen Tube.” Pp. 33-65 in Current Trends in the Embryology of Angiosperms.

Moscatelli, Alessandra, Fabrizio Ciampolini, Simona Rodighiero, Elisabetta Onelli, Mauro Cresti, Nadia Santo, and Aurora Idilli. 2007. "Distinct Endocytic Pathways Identified in Tobacco Pollen Tubes Using Charged Nanogold.” Journal of Cell Science 3804-19. Moschou, Panagiotis N., Ioannis D. Delis, Konstantinos A. Paschalidis, and Kalliopi A. Roubelakis-Angelakis. 2008. "Transgenic Tobacco Plants Overexpressing Polyamine Oxidase Are Not Able to Cope with Oxidative Burst Generated by Abiotic Factors." Physiologia Plantarum 133(2):140-56. 
Moschou, Panagiotis N., Konstantinos A. Paschalidis, loannis D. Delis, Athina H.

Andriopoulou, George D. Lagiotis, Dimitrios I. Yakoumakis, and Kalliopi A.

Roubelakis-Angelakis. 2008. "Spermidine Exodus and Oxidation in the Apoplast

Induced by Abiotic Stress Is Responsible for $\mathrm{H}_{2} \mathrm{O}_{2}$ Signatures That Direct Tolerance

Responses in Tobacco." The Plant Cell 20(May):1708-24.

Moschou, Panagiotis N. and Kalliopi A. Roubelakis-angelakis. 2014. "Polyamines and

Programmed Cell Death.” Journal of Experimental Botany 65(5):1285-96.

Moschou, Panagiotis N., Maite Sanmartin, Athina H. Andriopoulou, Enrique Rojo, Jose J.

Sanchez-Serrano, and Kalliopi A. Roubelakis-Angelakis. 2008. "Bridging the Gap between Plant and Mammalian Polyamine Catabolism: A Novel Peroxisomal Polyamine

Oxidase Responsible for a Full Back-Conversion Pathway in Arabidopsis.” Plant Physiology 147(August):1845-57.

Moutinho, Ana, Luísa Camacho, Ann Haley M. Salomé Pais, Anthony Trewavas, and Rui Malhó. 2001. “Antisense Perturbation of Protein Function in Living Pollen Tubes.” Sex Plant Reprod 14:101-4.

Murase, Kohji, Hiroshi Shiba, Megumi Iwano, Fang-Sik Che, Masao Watanabe, Akira Isogai, and Seiji Takayama. 2004. "A Membrane-Anchored Protein Kinase Involved in Brassica Self-Incompatibility Signaling.” Science 303.

Neill, Steven, Raimundo Barros, Jo Bright, Radhika Desikan, John Hancock, Judith Harrison, Peter Morris, Dimas Ribeiro, and Ian Wilson. 2008. "Nitric Oxide, Stomatal Closure, and Abiotic Stress.” Journal of Experimental Botany 59(February 2014):165-76.

Pasqualini, S., M. Cresti, C. Del Casino, C. Faleri, G. Frenguelli, E. Tedeschini, and L. Ederli. 2015. "Roles for NO and ROS Signalling in Pollen Germination and PollenTube Elongation in Cupressus Arizonica.” Biologia Plantarum 1-10.

Pegg, Anthony E. and Robert Anthony Casero. 2011. "Current Status of the Polyamine Research Field." Methods in Molecular Biology 13 D(7):3-35.

Pegg, Anthony E. and Anthony J. Michael. 2010. "Spermine Synthase.” Cellular and Molecular Life Sciences 67(1):113-21.

Peng, Xiongpo and Meng-xiang Sun. 2017. "Pollen Tube, a One-Way Special Train for Special Passengers.” Science Bulletin.

Picton, J. M. and M. W. Steer. 1983. "Evidence for the Role of Ca 2+ Ions in Tip Extension 
in Pollen Tubes.” Protoplasma 115:11-17.

Picton, Jill M. and Martin W. Steer. 1982. “A Model for the Mechanism of Tip Extension in Pollen Tubes." J. Theor. Biol. 98:15-20.

Pierson, E. S., Y. Q. Li, H. Q. Zhang, M. T. M. Willemse, H. F. Linskens, and M. Cresti. 1995. "Pulsatory Growth of Pollen Tubes : Investigation of a Possible Relationship with the Periodic Distribution of Cell Wall Components." Acta Bot. Neerl 44(June):121-28.

Pierson, E. S., D. D. Miller, D. A. Callaham, J. Van Aken, G. Hackett, and P. K. Hepler. 1996. "Tip-Localized Calcium Entry Fluctuates during Pollen Tube Growth.” Developmental Biology 174(0060):160-73.

Potocký, Martin, Mark A. Jones, Radek Bezvoda, Nicholas Smirnoff, and Viktor Žárský. 2007. "Reactive Oxygen Species Produced by NADPH Oxidase Are Involved in Pollen Tube Growth." New Phytologist 174(4):742-51.

Pottosin, Igor and Sergey Shabala. 2014. "Polyamines Control of Cation Transport across Plant Membranes: Implications for Ion Homeostasis and Abiotic Stress Signaling." Frontiers in Plant Science 5(April):1-17.

Pottosin, Igor, Ana María Velarde-Buendía, Jayakumar Bose, Isaac Zepeda-Jazo, Sergey Shabala, and Oxana Dobrovinskaya. 2014. "Cross-Talk between Reactive Oxygen Species and Polyamines in Regulation of Ion Transport across the Plasma Membrane: Implications for Plant Adaptive Responses.” Journal of Experimental Botany 65(5):1271-83.

Prado, Ana Margarida, D. Marshall Porterfield, and José A. Feijó. 2004. "Nitric Oxide Is Involved in Growth Regulation and Re-Orientation of Pollen Tubes." The Company of Biologists 2707-14.

Pradoa, Ana Margarida, Renato Colacxoa, Nuno Morenoa, Ana Catarina Silva, and Jose' A. Feijo. 2008. "Targeting of Pollen Tubes to Ovules Is Dependent on Nitric Oxide ( NO ) Signaling." Molecular Plant 1(4):703-14.

Prakash, L., Philip John, G. M. Nair, and G. Prathapasenan. 1988. "Effect of Spermidine and Methylglyoxal-Bis ( Guanyl-Hydrazone ) ( MGBG ) on In Vitro Pollen Germination and Tube Growth in Catharanthus Roseus.” Annals of Botany 61(February):373-75.

Quan, Li Juan, Bo Zhang, Wei Wei Shi, and Hong Yu Li. 2008. "Hydrogen Peroxide in Plants: A Versatile Molecule of the Reactive Oxygen Species Network.” Journal of 
Integrative Plant Biology 50(1):2-18.

Ren, Haiyun and Yun Xiang. 2007. "The Function of Actin-Binding Proteins in Pollen Tube Growth.” Protoplasma 230:171-82.

Romero, E. S'anchez-Rodr'1guez L. J. M. Ruiz. 2015. “Accumulation on Free Polyamines Enhanced Antioxidant Response in Fruit of Grafting Tomato Plants under Water Stress." Journal of Plant Physiology, 190, 72-78.

Rounds, Caleb M. and Magdalena Bezanilla. 2013. "Growth Mechanisms in Tip-Growing Plant Cells." Plant Biol. 64:243-65.

Sagor, G. H. M., Siyuan Zhang, Seiji Kojima, Stefan Simm, Thomas Berberich, and Tomonobu Kusano. 2016. "Reducing Cytoplasmic Polyamine Oxidase Activity in Arabidopsis Increases Salt and Drought Tolerance by Reducing Reactive Oxygen Species Production and Increasing Defense Gene Expression." Frontiers in Plant Science 7(February):1-16.

Scherer, Lisa J. and John J. Rossi. 2003. “Approaches for the Sequence-Specific Knockdown of MRNA.” Nature Biotechnology 21(12):1457-65.

Selinski, Jennifer and Renate Scheibe. 2014. "Pollen Tube Growth: Where Does the Energy Come From ?" Plant Signaling \& Behavior, v. 9(12); 2014.

Sharma, Vijay K., Cristel Carles, and Jennifer C. Fletcher. 2003. "Maintenance of Stem Cell Populations in Plants." PNAS 100:11823-29.

Shiu, Shin-han and Anthony B. Bleecker. 2001. "Receptor-like Kinases from Arabidopsis Form a Monophyletic Gene Family Related to Animal Receptor Kinases." PNAS 98(19):10763-68.

Shiu, Shin-han and Anthony B. Bleecker. 2003. "Expansion of the Receptor-Like Kinase / Pelle Gene Family and Receptor-Like Proteins in Arabidopsis." Plant Physiology 132(June):530-43.

Singh, Vineet K. and Rajesh Tandon. 2012. "Polyethylene Glycol and Polyamines Promote Pollen Germination and Tube Growth in Azadirachta Indica ( Meliaceae )." The International Journal of Plant Reproductive Biology 4(December):17-23.

Sírováa, Jana, Michaela Sedlá rováb, Jana Piterkováa, Lenka Luhováa, and Marek Petrivalsky. 2011. "The Role of Nitric Oxide in the Germination of Plant Seeds and Pollen.” Plant Science 181:560-72. 
Smith, C. I. Edvard and Rula Jain. 2019. "Therapeutic Oligonucleotides : State of the Art." Annu. Rev. Pharmacol. Toxicol 59:605-30.

Song, W. Y., G. L. Wang, L. L. Chen, H. S. Kim, L. Y. Pi, T. Holsten, and P. Ronald. 1995. "A Receptor Kinase-Like Protein Encoded by the Rice Disease Resistance Gene, Xa21." Science 270(December):2-4.

Sorkheh, K., B. Shiran, V. Rouhi, M. Khodambashi, J. N. Wolukau, and S. Ercisli. 2011.

"Response of in Vitro Pollen Germination and Pollen Tube Growth of Almond ( Prunus Dulcis Mill .) to Temperature, Polyamines and Polyamine Synthesis Inhibitor." Biochemical Systematics and Ecology 39:749-57.

Stein, C. A. 2001. "The Experimental Use of Antisense Oligonucleotides: A Guide for the Perplexed." The Journal of Clinical Investigation 108(5):641-44.

Steinhorst, Leonie and Jörg Kudla. 2012. "Calcium - a Central Regulator of Pollen Germination and Tube Growth." BBA - Molecular Cell Research (4C):9.

Sun, Chuanxin, Anna-Stina Hoglund, Helena Olsson, Elke Mangelsen, and Christer Jansson. 2005. "Antisense Oligodeoxynucleotide Inhibition as a Potent Strategy in Plant Biology : Identification of SUSIBA2 as a Transcriptional Activator in Plant Sugar Signalling." The Plant Journal 44:128-38.

Tang, Xiaoyan, Reid D. Frederick, Jianmin Zhou, Dennis A. Halterman, Yulin Jia, and Gregory B. Martin. 1996. "Initiation of Plant Disease Resistance by Physical Interaction of AvrPto and Pto Kinase." Science 274(December).

Tanou, Georgia, Vasileios Ziogas, Maya Belghazi, Anastasis Christou, Panagiota Filippou, Dominique Job, Vasileios Fotopoulos, and Athanassios Molassiotis. 2014. "Polyamines Reprogram Oxidative and Nitrosative Status and the Proteome of Citrus Plants Exposed to Salinity Stress." Plant, Cell and Environment 37(4):864-85.

Taylor, Loverine P. and Peter K. Hepler. 1997. "POLLEN GERMINATION AND TUBE GROWTH.” Аnпи. Rev. Plant Physiol 48:461-91.

Triantaphylidès, Christian and Michel Havaux. 2009. "Singlet Oxygen in Plants: Production, Detoxification and Signaling." Trends in Plant Science 14(4):219-28.

Tsutsumi, N., K. Kanayama, and S. Tano. 1992. "Suppression of ALPHA.-Amylase Gene Expression by Antisense Oligodeoxynucleotide in Barley Cultured Aleurone Layers." The Japanese Journal of Genetics 67:147-54. 
Tun, Ni Ni, Claudete Santa-Catarina, Tahmina Begum, Vanildo Silveira, Walter Handro, Eny Iochevet Segal Floh, and Günther F. E. Scherer. 2006. "Polyamines Induce Rapid Biosynthesis of Nitric Oxide (NO) in Arabidopsis Thaliana Seedlings." Plant and Cell Physiology 47(3):346-54.

Turpaev, K. T. 2002. "Reactive Oxygen Species and Regulation of Gene Expression." Biochemistry (Moscow) 67(3).

Walden, R., A. Cordeiro, and Antonio F. Tiburcio. 1997. "REVIEW: Polyamines: Small Molecules Triggering Pathways in Plant Growth and Development." Plant Physiology 113(4):1009-13.

Walker, J. C. and R. Zhang. 1990. "Relationship of a Putative Receptor Protein Kinase from Maize to the S-Locus Glycoproteins of Brassica." Nature 345.

Wang, Hao and Liwen Jiang. 2011. “Transient Expression and Analysis of Fluorescent Reporter Proteins in Plant Pollen Tubes.” Nature Protocols 6(4):419-26.

Wendehenne, David, Jörg Durner, and Daniel F. Klessig. 2004. "Nitric Oxide: A New Player in Plant Signalling and Defence Responses." Current Opinion in Plant Biology 7(4):449-55.

Wennerberg, Krister, Kent L. Rossman, and Channing J. Der. 2005. “The Ras Superfamily at a Glance." Journal of Cell Science 118:843-46.

Wolukau, Joseph N., Shao Ling Zhang, Guo Hua Xu, and Dixin Chen. 2004. "The Effect of Temperature, Polyamines and Polyamine Synthesis Inhibitor on in Vitro Pollen Germination and Pollen Tube Growth of Prunus Mume.” Scientia Horticulturae 99(34):289-99.

Wu, Hongjiang, Walt F. Lima, Hong Zhang, Amy Fan, Hong Sun, and Stanley T. Crooke. 2004. "Determination of the Role of the Human RNase H1 in the Pharmacology of DNA-like Antisense Drugs.” The Journal of Biological Chemistry 279(17):17181-89.

Wu, Juyou, Zhonglin Shang, Jun Wu, Xueting Jiang, Panagiotis N. Moschou, Wending Sun, Kalliopi A. Roubelakis-Angelakis, and Shaoling Zhang. 2010. "Spermidine OxidaseDerived H2O2regulates Pollen Plasma Membrane Hyperpolarization-Activated Ca2+Permeable Channels and Pollen Tube Growth.” Plant Journal 63(6):1042-53.

Yamasaki, Hideo and Michael F. Cohen. 2006. "NO Signal at the Crossroads: PolyamineInduced Nitric Oxide Synthesis in Plants?” Trends in Plant Science 11(11):519-22. 
Yan, An. 2010. "A Study of the Mechanism for Pollen Tube Growth.” University of California, Riverside.

Yen, Lung-fei, Xiong Liu, and Shutao Cai. 1995. "Polymerization of Actin from Maize Pollen '." Plant Physiology 107(1):73-76.

Ylstrs, Bauke, Jacqueline Busscher, John Franken, Peter C. H. Hollman, Joseph N. M. Mol, and Arjen J. Van Tunen. 1994. "Flavonols and Fertilization in Petunia Hybrida : Localization and Mode of Action during Pollen Tube Growth." The Plant Journa 6(2):201-12.

Zamecnik, Paul C. and Mary L. Stephenson. 1978. "Inhibition of Rous Sarcoma Virus Replication and Cell Transformation by a Specific Oligodeoxynucleotide." Proc. Nati. Acad. 75(1):280-84.

Zhang, Jie, Wei Li, Tingting Xiang, Zixu Liu, Kristin Laluk, Xiaojun Ding, Yan Zou, Minghui Gao, Xiaojuan Zhang, She Chen, Tesfaye Mengiste, Yuelin Zhang, and Jianmin Zhou. 2010. “Article Receptor-like Cytoplasmic Kinases Integrate Signaling from Multiple Plant Immune Receptors and Are Targeted by a Pseudomonas Syringae Effector." Cell Host and Microbe 7(4):290-301.

Zuker, Michael. 2003. "Mfold Web Server for Nucleic Acid Folding and Hybridization Prediction." Nucleic Acids Research 31(13):3406-15. 


\section{ACKNOWLEDGEMENTS}

I would like to thank my supervisor Dr. Attila Fehér for giving an opportunity to work in his research group and his guidance and all the opportunity that he has given me over the years. I would like to say thanks to my co-supervisor Dr. Katalin Gémes for her proper guidance and help during this work. While working here I have gathered immense experienceprofessionally, intellectually and personally. I am heartily thankful to all them for their mentorship and guidance.

I am also thankful for Dr. Ferhan Ayaydin for his valuable ideas, comments and suggestions on writing the thesis.

Many thanks to all of my colleagues from Biological Research Center, Laboratory of Functional Cell Biology:Ildikó Valkai, Ménesi Dalma, Lajkó Dézi Bianka, Bernula Dóra, Benkő Péter, Nikolett Judit Kaszler, and Nagy Róza who helped me a lot during my experiment and Péter performed reactive oxygen species and nitrogen oxide staining experiment for pollen germination and pollen tube length measurement of this work. I'd like to thank Dr. Györgyi for helping with oligo design and synthesis. Finally, I am thankful to my family and friends from Szeged for their valuable help and friendship that I will never forget.

This thesis work was supported by the grants from the Hungarian Ministry for National Economy, GINOP-2.3.2-15-2016-00001, and the National Research, Development and Innovation Funds of Hungary K101112 and FK128997. The author was a fellow of the Stipendium Hungaricum Scholarship Program managed by Tempus Public Foundation. 